POEF-SH-34

\title{
VERIFICATION OF CRITICALITY ACCIDENT ALARM SYSTEM DETECTOR LOCATIONS FOR THE X-326 PROCESS CELL FLOOR
}

August 1995

\author{
by \\ M. Christian Dobelbower \\ Jeffrey Woollard \\ Billy L. Lee, Jr. \\ Robert W, Tayloe, Jr. \\ Battelle
}

Under Contract 426215

to

LOCKHEED MARTIN UTILITY SERVICES, INC.

PORTSMOUTH GASEOUS DIFFUSION PLANT

P.O. Box 628 Piketon, Ohio 45661

Under Contract USECHQ-93-C-0001

to the

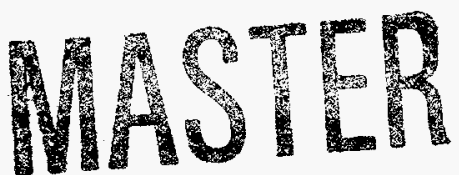

U.S. ENRICHMENT CORPORATION 


\section{NOTICE}

This report was prepared as an account of work sponsored by an agency of the United States Government. Neither the United States Government nor any agency thereof, nor any of their employees makes any warranty, express or implied, or assumes any legal liability or responsibility for the accuracy, completeness, or usefulness of any information, apparatus, product, or process disclosed, or represents that its use would not infringe privately owned rights. Reference herein to any specific commercial product, process, or service by trade name, trademark, manufacturer, or otherwise does not necessarily constitute or imply its endorsement, recommendation, or favoring by the United States Government or any agency thereof. The views and opinions of authors expressed herein do not necessarily state or reflect those of the United States Government or any agency thereof.

Available to DOE and DOE Contractors from the Office of Scientific and Technical Information, P.O. Box 62, Oak Ridge, TN 37831; prices available from (615) 576-8401, FTS/626-8401.

Available to the public from the National Technical Information Service, U.S. Department of Commerce, 5285 Port Royal Road, Springfield, VA 22161. 


\section{DISCLAIMER}

Portions of this document may be illegible in electronic image products. Images are produced from the best available original document. 


\section{DISTRIBUTION}

\section{LOCKHEED MARTIN UTILITY SERVICES, INC.}

\section{PORTSMOUTH}
J. Harris
R. Dunham
R. Oxenham
D. D'Aquila (10)
R. Lemming
Central Files (2)
J. Smith
X-710 Technical Library (2)
M. Plaster
Technical Review (2)
C. Dobelbower
B. Lee
R. Tayloe
J. Woollard
C. Skapik 
EXECUTIVE SUMMARY $\ldots \ldots \ldots \ldots \ldots \ldots \ldots \ldots \ldots$ iii

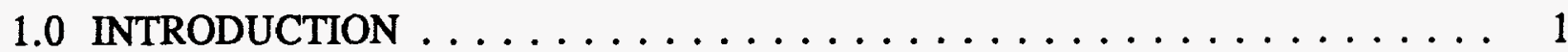

2.0 FACILITY DESCRIPTION $\ldots \ldots \ldots \ldots \ldots \ldots \ldots \ldots \ldots \ldots \ldots \ldots \ldots$

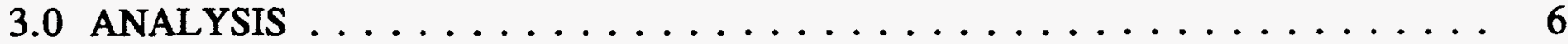

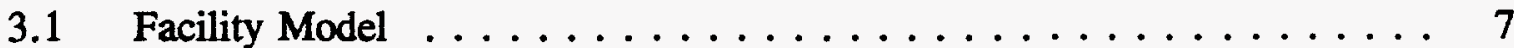

3.2 Source Term $\ldots \ldots \ldots \ldots \ldots \ldots \ldots \ldots \ldots \ldots \ldots$

3.3 Flux Tallies ......................... 19

3.4 Variance Reduction .................... 21

3.5 Flux to Absorbed Dose Rate Conversion . . . . . . . . . . . 21

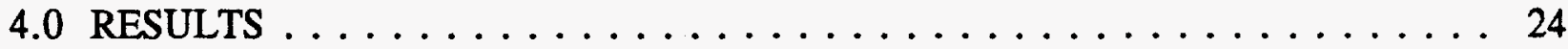

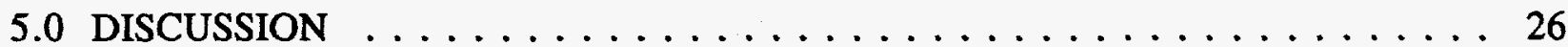

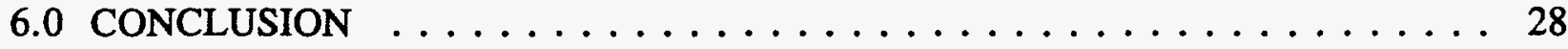

7.0 REFERENCES . . . . . . . . . . . . . . . . . . . . . . . . . . . . . . 29

Appendix A - MCNP Input File $\ldots \ldots \ldots \ldots \ldots \ldots \ldots \ldots \ldots \ldots$

Appendix B - Spreadsheets for Absorbed Dose Rate Calculations $\ldots \ldots \ldots \ldots$. . . . 32

\section{LIST OF TABLES}

Table 1. Material Compositions . . . . . . . . . . . . . . . . . . . 14

Table 2. Source Terms for $100 \%$ and $20 \%{ }^{235} \mathrm{U}$ Enriched Sources . . . . . . . . . 18

Table 3. Henderson Free-in-Air Flux-to-Dose Conversion Factors . . . . . . . . . . . 23

Table 4. Detector Response of Four Detectors Nearest S1 (the South Source) . . . . . 24

Table 5. Detector Response of Two Detectors Nearest S2 (the North Source) . . . . . 25

Table 6. Detector Response of Four Detectors Nearest S3 (the Middle Source) . . . . 25 


\section{LIST OF FIGURES}

Figure 1. A view of the cell floor of the X-326 process building showing the arrangement of units within the building. Also shown are the current locations of the CAAS detectors on the cell floor. (not to scale) $\ldots \ldots 4$

Figure 2. Side View of the North End of the X-326 Building Model . . . . . . . 8

Figure 3. The $\mathrm{X} 25 / \mathrm{X} 27$ Unit Model $\ldots \ldots \ldots \ldots \ldots \ldots \ldots$

Figure 4. The X-25-7 and Purge/Product Unit Models . . . . . . . . . . . . 11

Figure 5. The Arrangement of X25/X27, X-27-7 and Purge/Product Unit Models to Form the Process Cell Floor of the X-326 Building Model. (not to scale) . . . . . . . . . . . . . . . . . . . 12

Figure 6. SABRINA Representation of the South End of the X-326 Building Model, Including the X-25-7 and Purge/Product Unit Models . . . . . . 13

Figure 7. Source and Detector Locations on the Cell Floor in the X-326 Building Model . . . . . . . . . . . . . . . . . . 16

Figure 8. SABRINA Representation of the X-326 Building Model Cell Floor. (The modeled detectors are also shown.) $\ldots \ldots \ldots \ldots \ldots \ldots$ 


\section{EXECUTIVE SUMMARY}

Criticality Accident Alarm System (CAAS) detectors on the cell floor of the X-326 process building at the Portsmouth Gaseous Diffusion Plant (PORTS) are located at a height of $5 \mathrm{~m}$ above the cell floor. It has been suggested that this height be lowered to $1 \mathrm{~m}$ to alleviate accelerated system failures caused by the elevated temperatures at $5 \mathrm{~m}$ and to reduce the frequency of injury to maintenance personnel lifting the approximately 90-1b units into position. Work has been performed which analyzed the effect of relocating the CAAS detectors on the process floors of the X-333 and X-330 buildings from their current height to a height of $1 \mathrm{~m}^{1}$. This earlier work was based on criticality accidents occurring in low enriched material $\left(5 \%{ }^{235} \mathrm{U}\right)$ and was limited to the $\mathrm{X}-333$ and $\mathrm{X}-330$ buildings and the low enriched areas of X-326. It did not consider the residual higher enriched material in the X326 building. This report analyzes the effect on criticality alarm coverage of lowering the CAAS detectors. This analysis is based on criticality accidents resulting from higher enriched material which may be present as "hold-up" in the process equipment within the $\mathrm{X}$ 326 building.

The criticality accident alarm detectors at the PORTS facility are set to alarm at a neutron absorbed dose rate of $5 \mathrm{mrad} / \mathrm{hr}$. The calculated absorbed dose rates presented in this report show that the detectors examined that produce an alarm for the given criticality event at their current height will also produce an alarm if located at a height of 1 meter. Therefore, lowering the detectors will not result in a loss of coverage within the building. 


\subsection{INTRODUCTION}

The Portsmouth Gaseous Diffusion Plant (PORTS), located in Piketon, Ohio, is one of two operating gaseous diffusions plants leased from the U.S. Department of Energy (DOE) by the United States Enrichment Corporation (USEC) and managed and operated by Martin Marietta Utility Services (MMUS). At these plants, uranium (U), in the form of uranium hexafluoride $\left(\mathrm{UF}_{6}\right)$, is enriched via a gaseous diffusion process from its naturally occurring isotopic concentration of about $0.7 \%{ }^{235} \mathrm{U}$, up to about $5 \%{ }^{235} \mathrm{U}$. However, current operations allow a maximum production enrichment of $10 \%{ }^{235} \mathrm{U}$. The diffusion cascade process equipment is housed in buildings $\mathrm{X}-333, \mathrm{X}-330$, and $\mathrm{X}-326$.

Presently, Criticality Accident Alarm System (CAAS) detectors on the cell floor of the X-326 building are located at a height of $5 \mathrm{~m}$ above the cell floor. It has been suggested that this height be lowered to $1 \mathrm{~m}$. Lowering the detector height was deemed beneficial because it could reduce the potential for worker injury when the approximately 90 pound alarms were removed for maintenance. Also, due to the large thermal gradient present in the process building, lowering the detector would reduce the temperature of the detectors' operating environment. This may serve to reduce the incidence of battery failure resulting from elevated temperatures.

Previous work was performed that analyzed the effect of relocating the CAAS detectors on the process floors of the X-333, X-330, and the low enriched areas of X-326 from their current height of approximately $5 \mathrm{~m}$ to a height of approximately $1 \mathrm{~m}$ (ref 1). This earlier work was based on criticality accidents occurring in low enriched material (5\% ${ }^{235} \mathrm{U}$ ). It did not apply to the the high enriched material in the $\mathrm{X}-326$ building. The purpose of this report is to analyze the effect on criticality alarm coverage of lowering the CAAS detectors on the cell floor of the X-326 building from a height of $5 \mathrm{~m}$ to a height of $1 \mathrm{~m}$, and to verify existing coverage at their current height. This analysis is based on criticality 
POEF-SH-34

accidents resulting from the higher enriched material which may be present as "hold-up" in the process equipment within the $\mathrm{X}-326$ building. 


\subsection{FACILITY DESCRIPTION}

The X-326 process facility is comprised of the X-326 building and all the cascade process equipment contained within the building. The $X-326$ building is a two story building approximately $2,230 \mathrm{ft}$ long, $552 \mathrm{ft}$ wide and $62 \mathrm{ft}$ high. Its two floors have a combined floor space of approximately 58 acres $^{2}$. The lower floor, called the operating floor, contains the electrical switch gear and control instrumentation, while the upper floor, called the cell floor, contains the diffusion process equipment.

On the cell floor, the diffusion process takes place in stages. Twelve stages are grouped together in a process cell. Purge cells have six stages per cell. Twenty process cells are then, in turn, grouped together into units. The X-326 process building contains three different types of units, $\mathrm{X}-25$ units, $\mathrm{X}-27$ units, and purge and product units. The arrangement of these different types of units within the process building is shown in Figure 1. ${ }^{12,13}$ Units X-27-1 through X-27-3 and units X-25-1 through X-25-6 each contain 20 process cells. The X-25-7 unit and the purge and product unit each contain 10 cells. Uranium leaves each stage in two streams, a slightly enriched stream and a slightly depleted stream. The enriched stream from each stage is used as feed to the following stage. All of the stages are then connected to form an enrichment cascade.

Uranium in the cascade process equipment is in the chemical form $\mathrm{UF}_{6}$. In the past, uranium entered the northeast corner of the X-326 building with an enrichment of approximately $5 \%{ }^{235} \mathrm{U}$ and was further enriched to assays of greater than $97 \%{ }^{235} \mathrm{U}$. Presently, the X-326 facility is primarily used as a top end for the enrichment process, with a top enrichment of about $10 \%{ }^{235} \mathrm{U}$.

Several CAAS detectors are located throughout the X-326 building. Twelve detectors are currently located on the cell floor above the cascade process equipment (ref 8 ). These 
POEF-SH-34

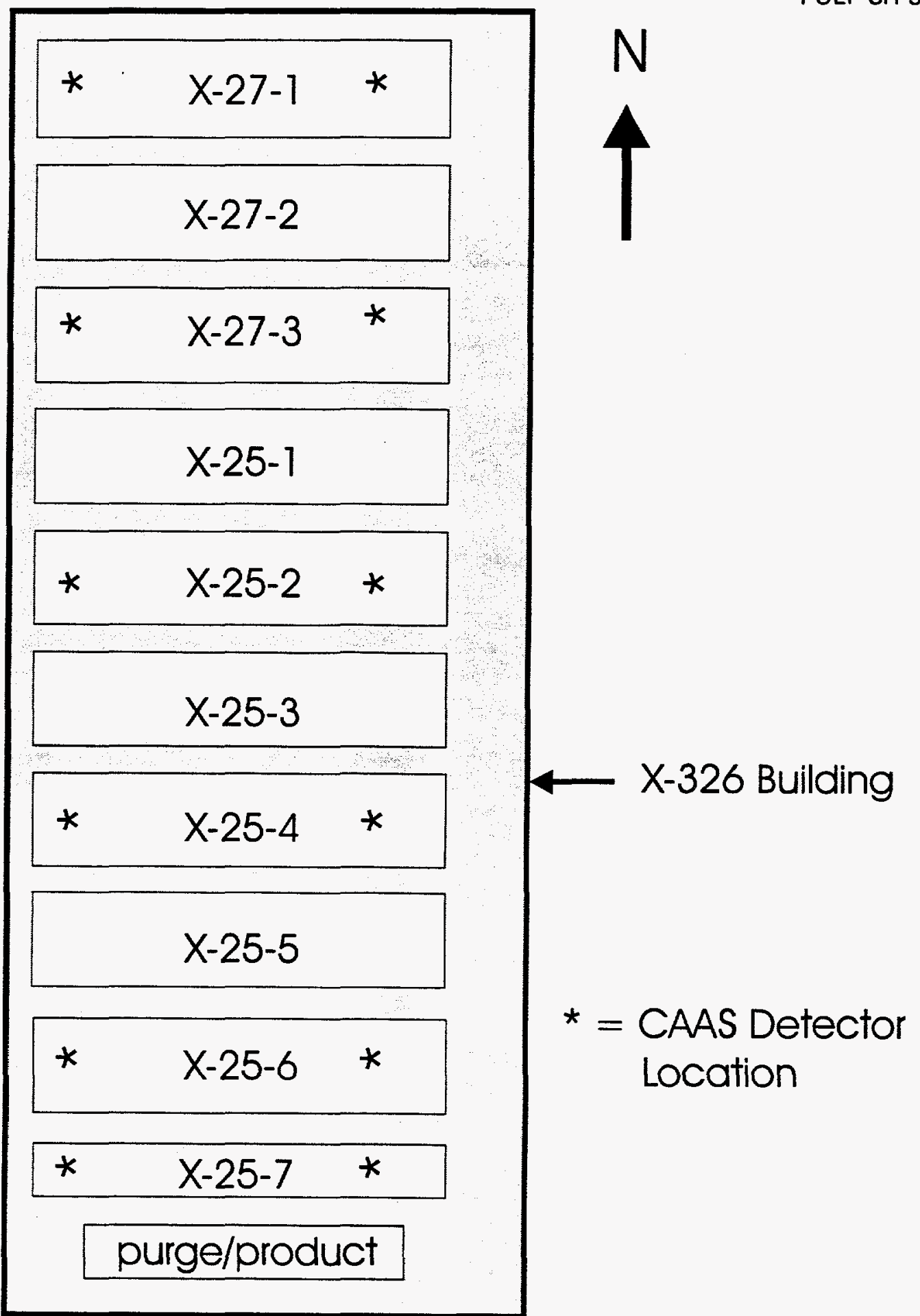

Figure 1. A view of the cell floor of the X-326 process building showing the arrangement of units within the building. Also shown are the current locations of the CAAS detectors on the cell floor. (not to scale) 
POEF-SH-34

detectors are mounted on vertical support columns at a height of $5 \mathrm{~m}$ above the process cell floor. The location of each of these detectors is shown in Figure 1. 


\subsection{ANALYSIS}

The CAAS detectors on the cell floor of the X-326 building are located at a height of $5 \mathrm{~m}$. As previously discussed, it has been suggested that these detectors be relocated to a height of $1 \mathrm{~m}$. An analysis has been performed using the monte carlo code $\mathrm{MCNP}^{3}$ to determine the impact of lowering the CAAS detectors on the extent of criticality accident alarm coverage provided on the process cell floor.

To determine the effect of lowering these detectors, an MCNP model of the X-326 building was developed. In this model, CAAS detectors were modeled at positions corresponding to the existing CAAS detectors and at their proposed new positions (on the same columns but at a height of $1 \mathrm{~m}$ ). Next, criticality accidents were modeled at various locations throughout the facility and the detector response was calculated for each detector location. Finally, the response of the detectors at the $1 \mathrm{~m}$ height was compared to the response of the detectors at the $5 \mathrm{~m}$ height to determine if criticality alarm coverage on the process cell floor is maintained.

The development of the MCNP model and the analysis of the results was performed in five steps. First, a suitable geometry, approximating the facility, was developed. Second, an accurate source term describing an appropriate criticality event was determined. Third, the CAAS detectors were modeled and flux tallies were implemented in a manner which provided an accurate value of the flux spectrum at the detector locations. Fourth, variance reduction techniques were employed such that the problem could be solved in a timely manner while still generating accurate results. Finally, a flux to dose conversion was applied to the tally results to determine the CAAS detector's response. These five steps are described in detail in the sections that follow. 


\subsection{Facility Model}

The X-326 building was modeled as a two-story structure, $2280 \mathrm{ft}$ long by $552 \mathrm{ft}$ wide and $62 \mathrm{ft}$ tall. ${ }^{10,11,14}$ A side view of one end of the X-326 building model, which indicates floor and ceiling heights, is shown in Figure 2. The first floor of the building was modeled as a large empty bay, $21 \mathrm{ft}$ high. The second floor was separated from the first floor by an 8-in thick concrete slab. The second floor was modeled as $38 \mathrm{ft}$ high and contains the process cells. A 4-in thick tar and steel roof was modeled covering the building. ${ }^{4}$ The ground was modeled as a 1-ft thick slab of concrete. Finally, a large hemisphere of air (with a radius of $8 \mathrm{~km}$ ) surrounding the building was included in the model.

The process cell floor of the X-326 building contains all of the process units. Three different types of process units were modeled. The first process unit model (denoted $X 25 / X 27$ ) represents an X-27 unit (units 1-3) or an X-25 unit (units 1-6). The second unit modeled (denoted X-25-7) represents unit X-25-7. The third unit modeled (denoted Purge/Product) represents the purge and product unit. Each of these unit models is discussed briefly below.

X25/X27 Unit Model: The X25/X27 unit model consists of 20 process cells. Each process cell is approximately $87 \mathrm{ft}$ long by $33 \mathrm{ft} 9$ in wide by $11 \mathrm{ft} 2$ in tall. The length and width of the process cell were taken from references 15 and 16. Process cell heights varied across the cell. For the model, an average value was used. In order to maintain consistency with previous calculations, this value was taken from reference 4. Each unit consists of 2 rows of 10 process cells. The rows of cells are separated by $27 \mathrm{ft}$ of air. ${ }^{15,16}$ Within each row, the cells are separated by $14 \mathrm{ft}$ of air. This unit model is illustrated in Figure 3.

X-25-7 Unit Model: The X-25-7 unit was modeled as a single row of 10 process cells. The dimensions of the process cells in this unit are identical to the process cell 
POEF-SH-34

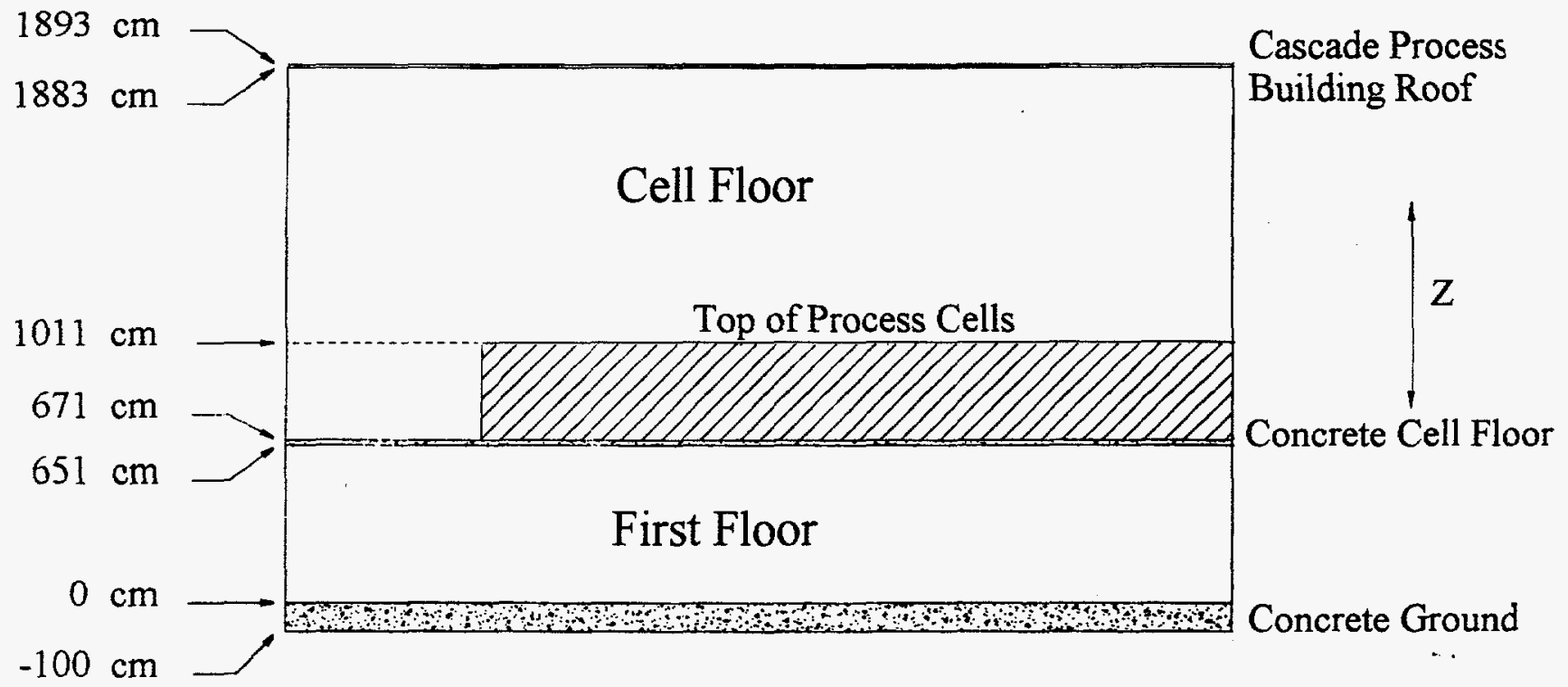

Figure 2. Side View of the North End of the X-326 Building Model 
POEF-SH-34

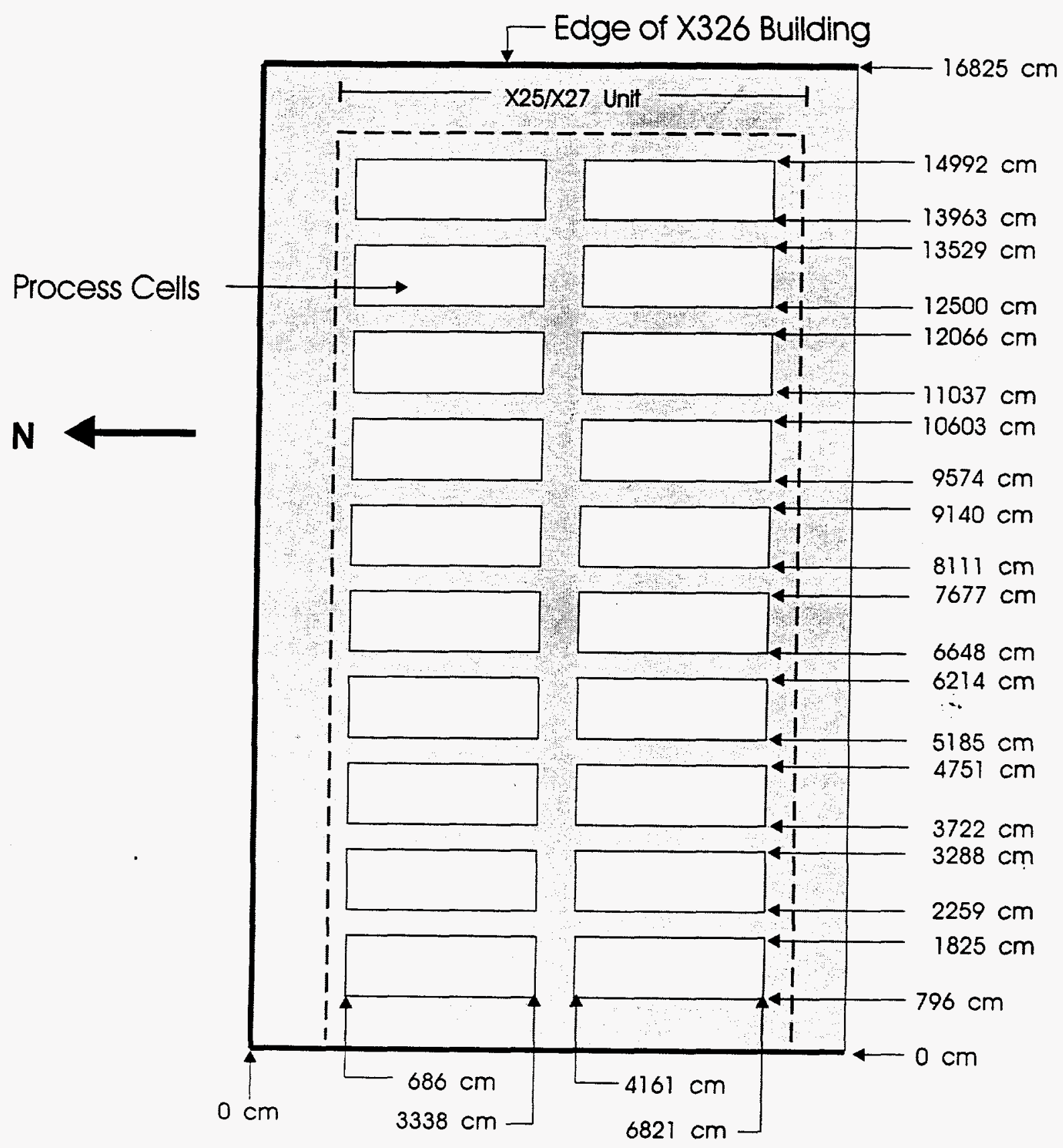

Figure 3. The X25/X27 Unit Model

August 1995 
POEF-SH-34

dimensions in the $X 25 / X 27$ unit model. The $X-25-7$ unit model is shown in Figure 4 .

Purge/Product Unit Model: The purge and product unit was modeled as a single row of 10 process cells. The process cells in this unit are of varying size; however, they are always smaller than the cells in the X25/X27 unit model. The Purge/Product unit model is also shown in Figure 4.

These three different unit models were then arranged to form the model of the X-326 building process floor. Nine of the X25/X27 unit models were placed side by side along the building's west wall, starting from the north end of the building. The ninth $X 25 / X 27$ unit model is followed by the X-25-7 unit model. This, in turn, is followed by the Purge/Product unit model. The air between each unit is accounted for in the unit models. The arrangement of all of the unit models is shown in Figure 5. Additionally, a Sabrina ${ }^{5}$ representation of the south end of the building model, showing the X-25-7 and Purge/Product unit models, is shown in Figure 6.

For consistency with previous calculations of criticality accident alarm detector response in the PORTS buildings, the number densities used in this analysis were taken from reference 4. The actual number densities used throughout the report are given in Table 1. 


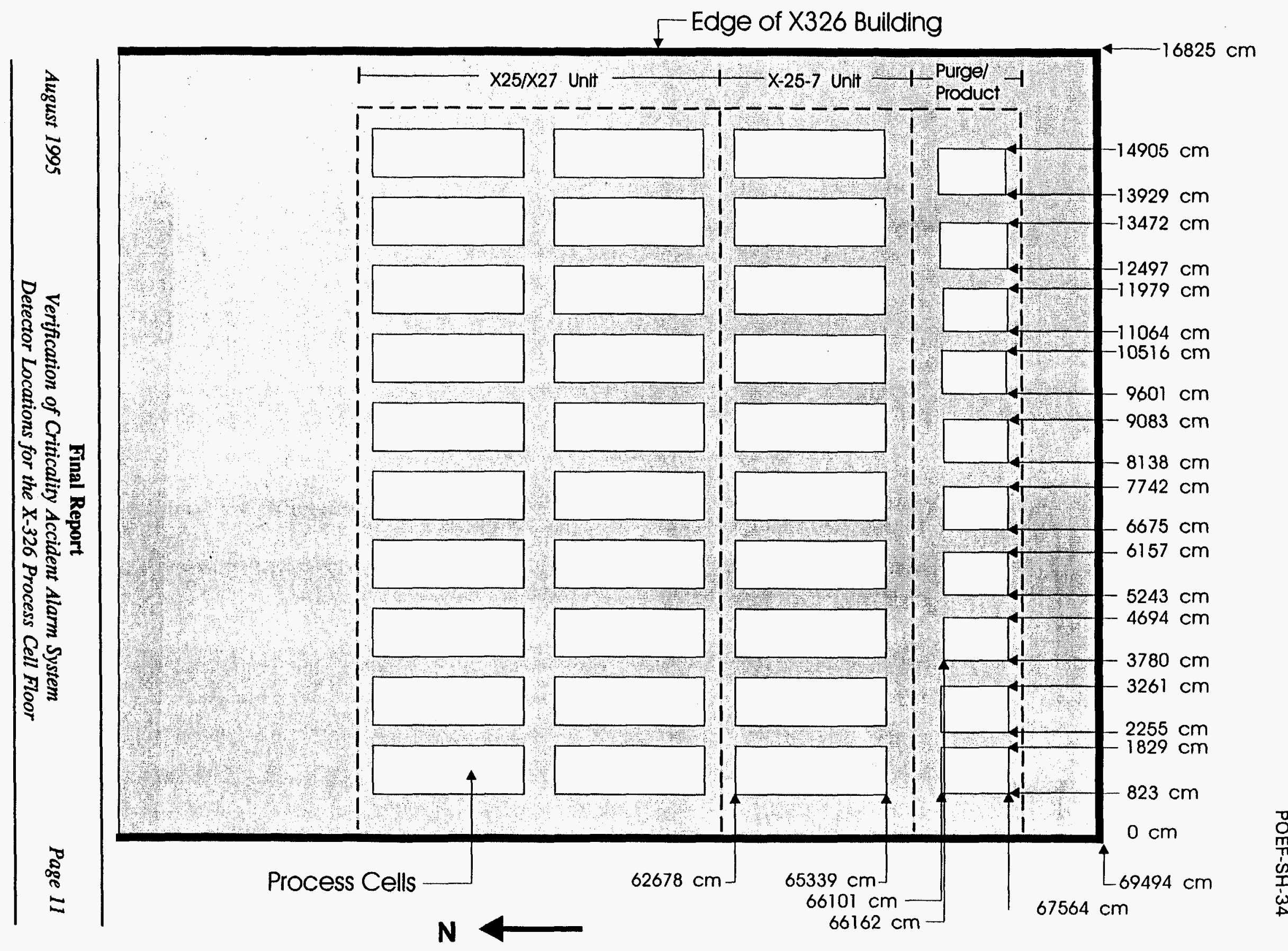

Figure 4. The X-25-7 and Purge/Product Unit Models 


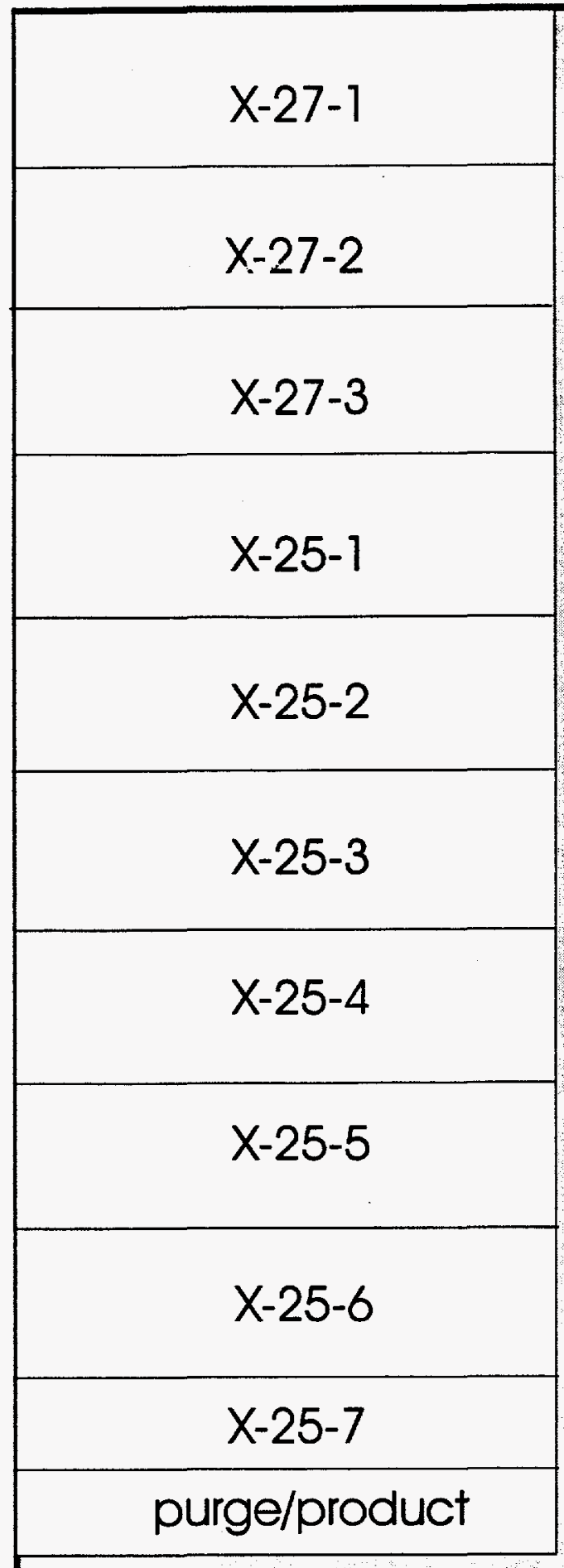

N

POEF-SH-34

X326 Building

Figure 5. The Arrangement of X25/X27, X-27-7 and Purge/Product Unit Models to Form the Process Cell Floor of the X-326 Building Model. (not to scale) 

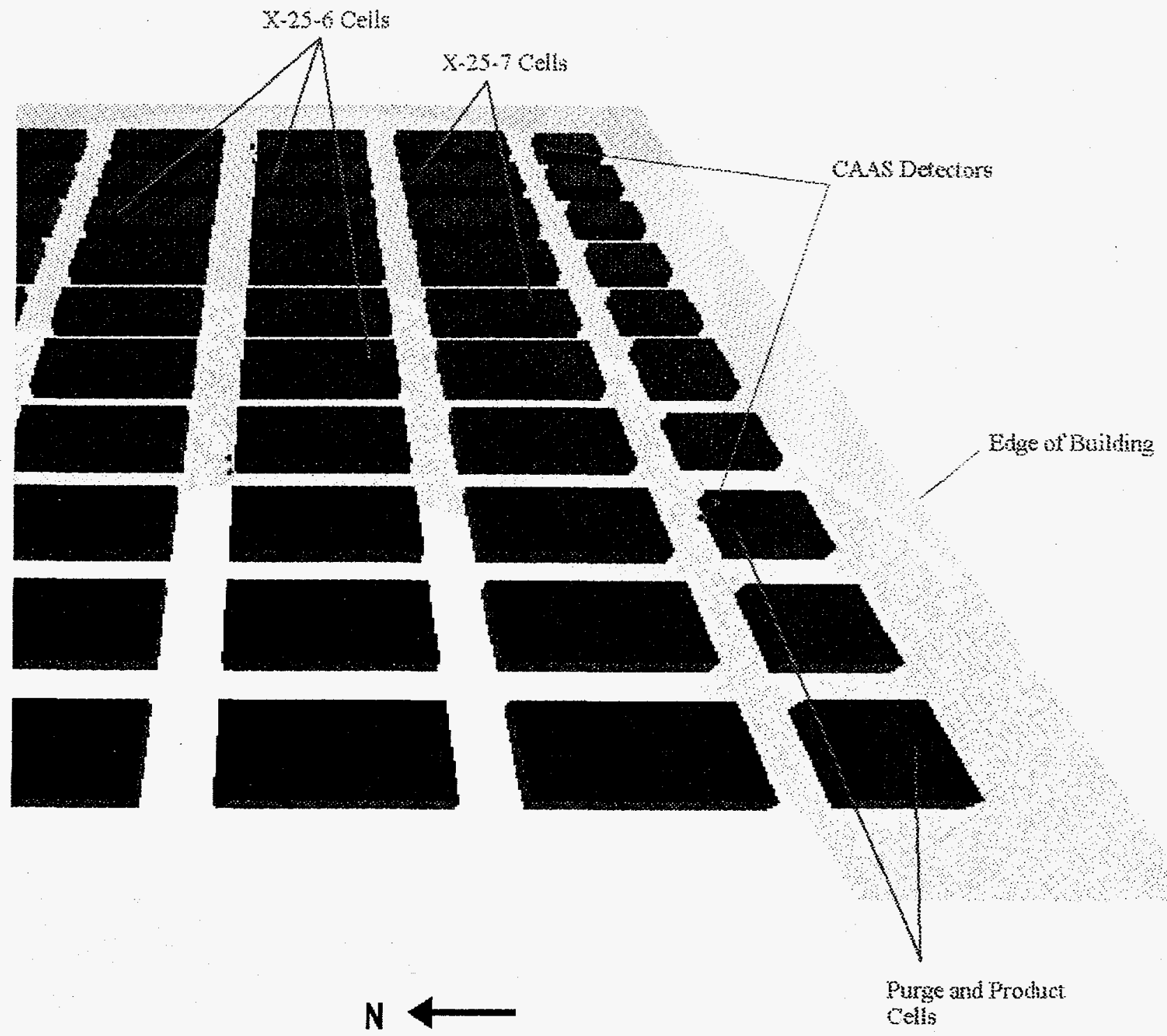

Purate and Frodict Cels

Figure 6. SABRINA Representation of the South End of the X-326 Building Model, Including the X-25-7 and Purge/Product Unit Models 
Table 1. Material Compositions

\begin{tabular}{|c|c|c|}
\hline Material & Element & $\begin{array}{l}\text { Number Density } \\
\text { (Atom barn' }{ }^{1} \mathrm{~cm}^{-1} \text { ) }\end{array}$ \\
\hline \multirow[t]{2}{*}{ Air } & Nitrogen & $3.570 \mathrm{E}-05$ \\
\hline & Oxygen & $7.840 \mathrm{E}-06$ \\
\hline \multirow[t]{9}{*}{ Concrete } & Hydrogen & $1.487 \mathrm{E}-02$ \\
\hline & Carbon & $3.814 \mathrm{E}-03$ \\
\hline & Oxygen & $4.152 \mathrm{E}-02$ \\
\hline & Sodium & $3.040 \mathrm{E}-04$ \\
\hline & Magnesium & $5.870 \mathrm{E}-04$ \\
\hline & Aluminum & 7.350E-04 \\
\hline & Silicon & $6.037 \mathrm{E}-03$ \\
\hline & Calcium & $1.159 \mathrm{E}-02$ \\
\hline & Iron & $1.968 \mathrm{E}-04$ \\
\hline \multirow[t]{2}{*}{ Steel } & Carbon & $3.921 \mathrm{E}-03$ \\
\hline & Iron & 8.349E-02 \\
\hline \multirow[t]{10}{*}{ Homogenized Cell Material } & Carbon & $6.230 \mathrm{E}-05$ \\
\hline & Fluorine & $8.880 \mathrm{E}-05$ \\
\hline & Aluminum & $8.420 \mathrm{E}-05$ \\
\hline & Silicon & $1.666 \mathrm{E}-05$ \\
\hline & Chlorine & $8.880 \mathrm{E}-05$ \\
\hline & Chromium & $1.619 \mathrm{E}-04$ \\
\hline & Manganese & $1.703 \mathrm{E}-05$ \\
\hline & Iron & $5.934 \mathrm{E}-04$ \\
\hline & Nickel & 4.563E-04 \\
\hline & Copper & $3.273 \mathrm{E}-05$ \\
\hline \multirow[t]{4}{*}{ Homogenized Roof } & Hydrogen & $4.288 \mathrm{E}-02$ \\
\hline & Carbon & $1.812 \mathrm{E}-02$ \\
\hline & Oxygen & $1.896 \mathrm{E}-03$ \\
\hline & Iron & $2.783 \mathrm{E}-02$ \\
\hline
\end{tabular}




\subsection{Source Term}

To completely model the criticality accident sources used in the MCNP analysis, the source location, source neutron production rate (power level), and the source neutron energy spectra must be known. The development of each is discussed briefly below.

\subsubsection{Source Locations}

Source locations were chosen such that when the detectors are lowered to a height of $1 \mathrm{~m}$ above the process floor, the thickness of homogenized process cell between the source and the detector would be maximized. Since the homogenized process cell is the primary attenuating medium in the facility, these source locations result in the smallest absorbed dose rates at the detectors. Therefore, any other source location would result in a smaller thickness of homogenized process cell between the source and detector and will be bounded by the cases analyzed.

Three different source locations were utilized in this analysis. The first source, S1, was located in the Purge/Product unit model at the south end of the building. The second source, S2, was located in the X-27-1 unit model at the north end of the building. The third source, S3, was placed in the X-25-1 unit model. All source locations are shown in Figure 7. 


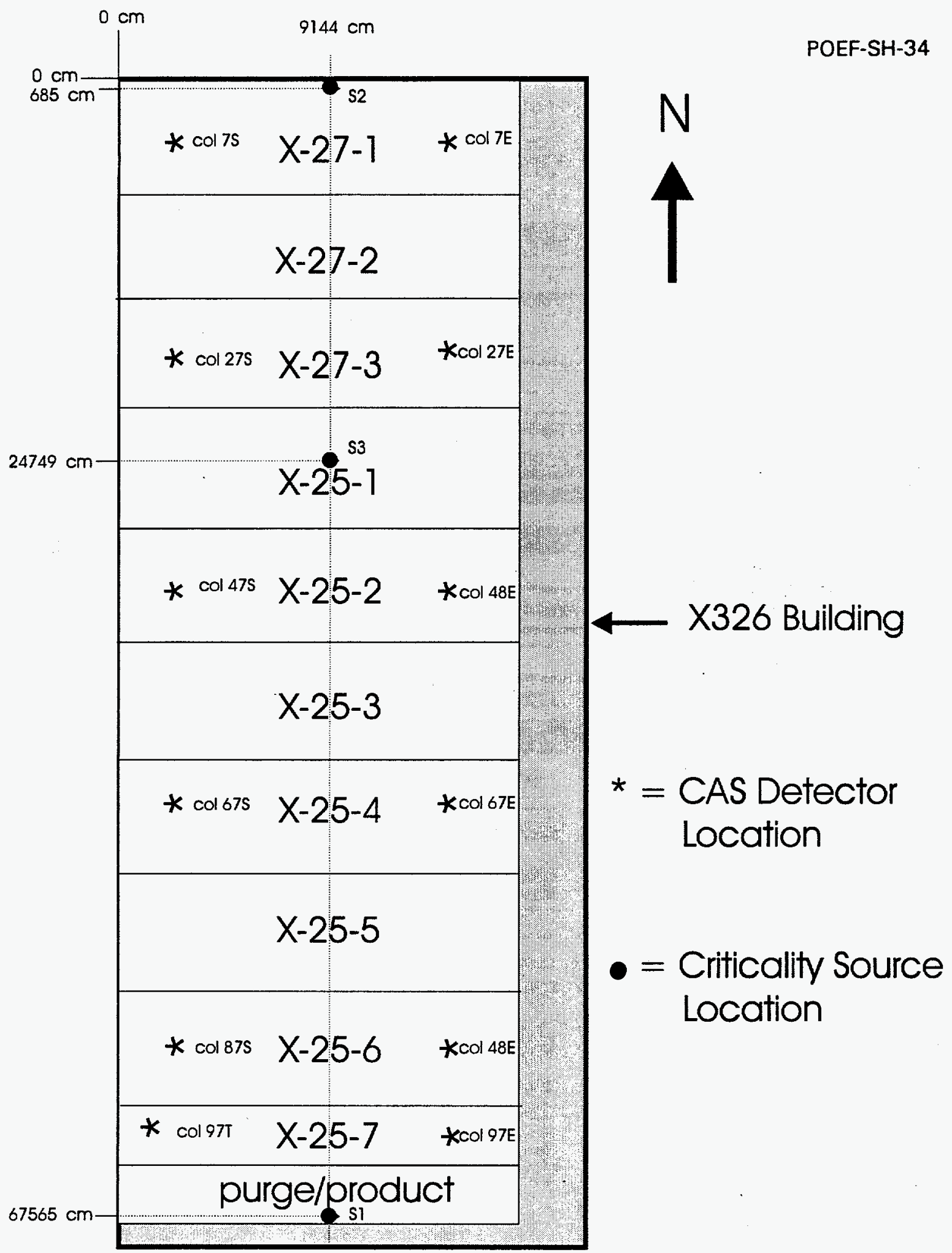

Figure 7. Source and Detector Locations on the Cell Floor in the X-326 Building Model 


\subsubsection{Source Strength}

The criticality sources used in this analysis were those that result in the minimum critical accident of concern as defined in ANSI/ANS 8.3-1986. ${ }^{6}$ The source strengths used varied with the location of the source in the facility. As the $\mathrm{UF}_{6}$ material moves through the cascade in the process building the ${ }^{235} \mathrm{U}$ enrichment increases. Therefore, the criticality accidents that may occur in different locations in the building will most likely result from material enriched to different levels. As shown in POEF-SH-31, neutron energy spectra and power levels for the minimum critical accident of concern vary for sources with different ${ }^{235} \mathrm{U}$ enrichments. ${ }^{7}$

In this analysis, the neutron energy spectra and power level for $\mathrm{S} 1$, in the north end of the building, were those that result from the minimum critical accident of concern for an optimally moderated sphere of $\mathrm{UO}_{2} \mathrm{~F}_{2}$ with a ${ }^{235} \mathrm{U}$ enrichment of $20 \%$. This is representative of the enrichment which previously entered the facility. Although the $\mathrm{UF}_{6}$ entering the $\mathrm{X}$ 326 building is no longer enriched to $20 \%{ }^{235} \mathrm{U}$, material with this enrichment may still be present in the building. Additionally, a minimum accident of concern from an optimally moderated $20 \%{ }^{235} \mathrm{U}$ sphere will produce a lower detector response than that of a minimum accident of concern from an optimally moderated $10 \%{ }^{235} \mathrm{U}$ sphere. Therefore, $20 \%{ }^{235} \mathrm{U}$ was considered in the analysis. The neutron energy spectra and power level for $\mathrm{S} 2$, in the south end of the building, were those that result from the minimum critical accident of concern for an optimally moderated sphere of $U_{6}$ with a ${ }^{235} \mathrm{U}$ enrichment of $100 \%$. This is representative of the material which previously exited the facility. Again, material with this level of ${ }^{235} \mathrm{U}$ enrichment is no longer produced by the process equipment. However, this material may also still be present in the building or process equipment and was, therefore, considered in the analysis. Finally, the neutron energy spectra and power level for S3, approximately in the middle of the building, were those that result from the minimum critical accident of concern for an optimally moderated sphere of $U_{6}$ with a ${ }^{235} \mathrm{U}$ enrichment of $20 \%$. 
All power levels and neutron source spectra were taken from POEF-SH-31 assuming the Henderson flux to dose response function. ${ }^{7}$ Source strengths for both the $20 \%$ and $100 \%$ ${ }^{235} \mathrm{U}$ enriched sources are tabulated in Table 2. All sources were modeled as isotropic point sources and were placed at a height of $1 \mathrm{~m}$ above the process floor. This height was chosen to provide consistency with previous calculations ${ }^{1}$.

Table 2. Source Terms for $100 \%$ and $20 \%{ }^{235} \mathrm{U}$ Enriched Sources

\begin{tabular}{|c|c|c|}
\hline \multirow{2}{*}{ Upper Energy Limit (MeV) } & \multicolumn{2}{|c|}{ Source Strength (number $\mathrm{cm}^{2} \mathrm{~s}^{1} \mathrm{~W}^{1}$ ) } \\
\hline & $20 \%$ 235 Unriched & $100 \%{ }^{235} \mathrm{U}$ Enriched \\
\hline $2.00 \mathrm{E}+01$ & $8.56 \mathrm{E}+02$ & $1.28 \mathrm{E}+03$ \\
\hline $6.43 \mathrm{E}+00$ & $6.84 \mathrm{E}+03$ & $1.02 \mathrm{E}+04$ \\
\hline $3.00 \mathrm{E}+00$ & $7.43 \mathrm{E}+03$ & $1.13 \mathrm{E}+04$ \\
\hline $1.85 \mathrm{E}+00$ & $3.89 \mathrm{E}+03$ & $5.88 \mathrm{E}+03$ \\
\hline $1.40 \mathrm{E}+00$ & $4.74 \mathrm{E}+03$ & $7.25 \mathrm{E}+03$ \\
\hline $9.00 \mathrm{E}-01$ & $6.66 \mathrm{E}+03$ & $1.03 E+04$ \\
\hline $4.00 \mathrm{E}-01$ & $5.67 \mathrm{E}+03$ & $8.89 E+03$ \\
\hline $1.00 \mathrm{E}-01$ & $3.81 \mathrm{E}+03$ & $5.83 E+03$ \\
\hline $1.70 \mathrm{E}-02$ & $2.77 \mathrm{E}+03$ & $3.99 E+03$ \\
\hline $3.00 \mathrm{E}-03$ & $2.41 \mathrm{E}+03$ & $3.52 \mathrm{E}+03$ \\
\hline 5.50E-04 & $2.27 \mathrm{E}+03$ & $3.21 \mathrm{E}+03$ \\
\hline $1.00 \mathrm{E}-04$ & $1.52 \mathrm{E}+03$ & $2.09 \mathrm{E}+03$ \\
\hline $3.00 \mathrm{E}-05$ & $1.25 E+03$ & $1.71 E+03$ \\
\hline $1.00 \mathrm{E}-05$ & $1.30 \mathrm{E}+03$ & $1.79 \mathrm{E}+03$ \\
\hline $3.05 E-06$ & $5.72 \mathrm{E}+02$ & $7.91 \mathrm{E}+02$ \\
\hline $1.77 \mathrm{E}-06$ & $3.31 E+02$ & $4.79 \mathrm{E}+02$ \\
\hline $1.30 \mathrm{E}-06$ & $1.40 \mathrm{E}+02$ & $1.92 \mathrm{E}+02$ \\
\hline $1.13 E-06$ & $1.39 \mathrm{E}+02$ & $1.68 \mathrm{E}+02$ \\
\hline
\end{tabular}




\begin{tabular}{||c|c|c||}
\hline Upper Energy Limit (MeV) & Source Strength (number $\left.\mathrm{cm}^{-2} \mathrm{~s}^{-1} \mathrm{~W}^{-1}\right)$ \\
\hline $1.00 \mathrm{E}-06$ & $20 \%{ }^{235} \mathrm{U}$ Enriched & $100 \%{ }^{235} \mathrm{U}$ Enriched \\
\hline $8.00 \mathrm{E}-07$ & $2.44 \mathrm{E}+02$ & $3.17 \mathrm{E}+02$ \\
\hline $4.00 \mathrm{E}-07$ & $7.40 \mathrm{E}+02$ & $9.66 \mathrm{E}+02$ \\
\hline $3.25 \mathrm{E}-07$ & $2.29 \mathrm{E}+02$ & $2.74 \mathrm{E}+02$ \\
\hline $2.25 \mathrm{E}-07$ & $3.83 \mathrm{E}+02$ & $4.84 \mathrm{E}+02$ \\
\hline $1.00 \mathrm{E}-07$ & $1.38 \mathrm{E}+03$ & $1.29 \mathrm{E}+03$ \\
\hline $5.00 \mathrm{E}-08$ & $1.97 \mathrm{E}+03$ & $1.28 \mathrm{E}+03$ \\
\hline $3.00 \mathrm{E}-08$ & $1.24 \mathrm{E}+03$ & $7.14 \mathrm{E}+02$ \\
\hline $1.00 \mathrm{E}-08$ & $1.11 \mathrm{E}+03$ & $5.67 \mathrm{E}+02$ \\
\hline $1.00 \mathrm{E}-11$ & $1.80 \mathrm{E}+02$ & $1.04 \mathrm{E}+02$ \\
\hline & $0.00 \mathrm{E}+00$ & $0.00 \mathrm{E}+00$ \\
\hline
\end{tabular}

\subsection{Flux Tallies}

The CAAS detectors used in the X-326 building at PORTS are set to alarm at an absorbed dose rate in tissue of $5 \mathrm{mrad} / \mathrm{hr}^{9}$. Values of the neutron flux in air, calculated by MCNP, are converted to absorbed dose rates through the use of an appropriate flux to absorbed dose rate conversion factor (see section 3.5). Therefore, the detectors modeled in MCNP must tally the neutron flux spectra in air.

The CAAS detectors were modeled as spheres of air with a $1 \mathrm{~m}$ diameter. The detectors were modeled at heights of 1 and $5 \mathrm{~m}$ above the process cell floor at positions corresponding to their current locations ${ }^{8}$. These detector locations are the same as those shown in Figure 1. The neutron fluence at the various detectors was calculated using a track length estimator of neutron fluence in the detector sphere. A SABRINA representation of the $\mathrm{X}-326$ building model cell floor, including the modeled detectors, is shown in Figure 8. 

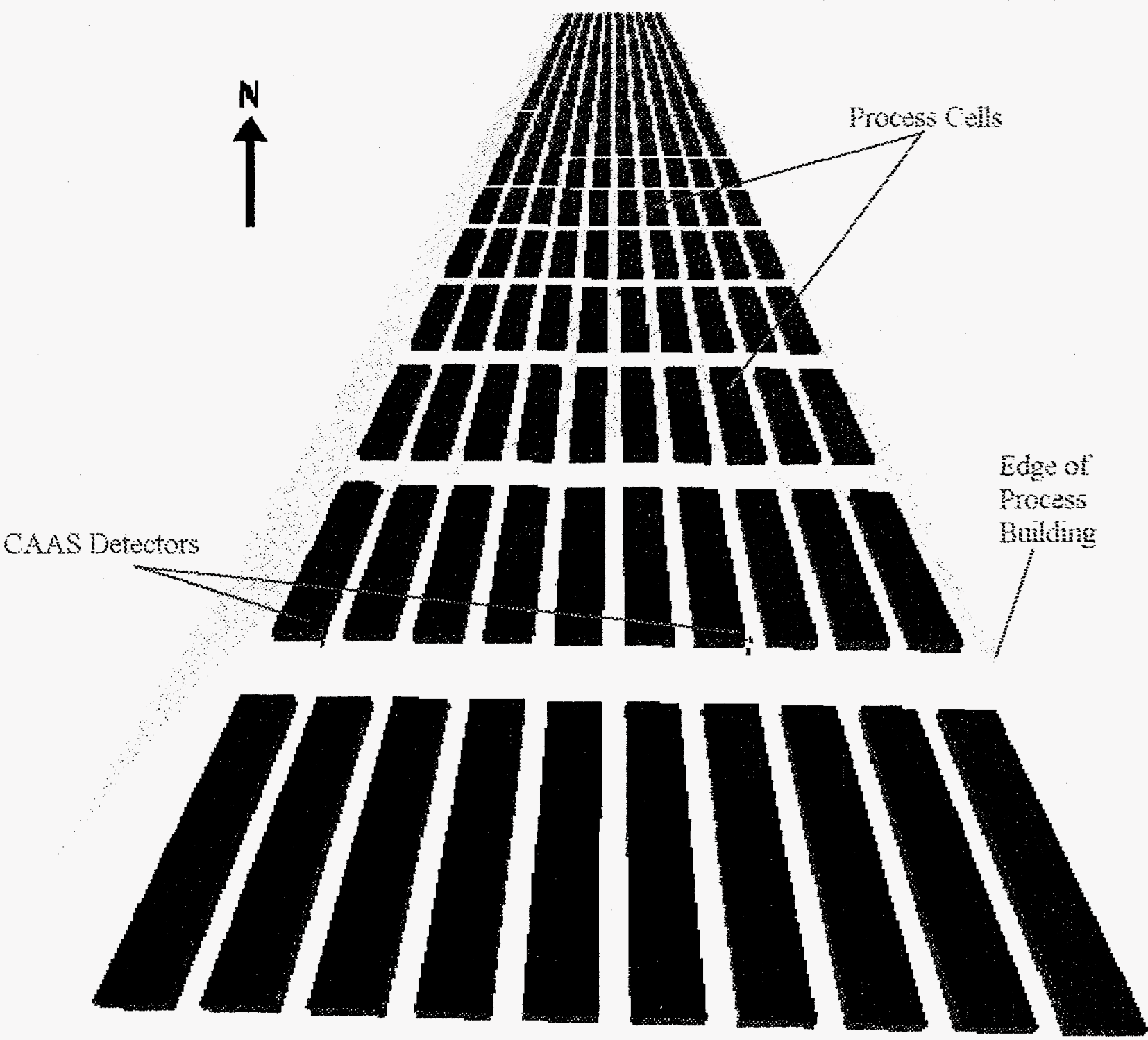

Figure 8. SABRINA Representation of the X-326 Building Model Cell Floor. (The modeled detectors are also shown.) 


\subsection{Variance Reduction}

This problem was run as an analog monte carlo problem and, as such, variance reduction was not implemented.

\subsection{Flux to Absorbed Dose Rate Conversion}

MCNP calculated the neutron fluence per source neutron at the modeled detector locations. In order to calculate the absorbed dose rate in the detector, the neutron fluence per source neutron was first converted to neutron flux. Then, a flux to neutron absorbed dose rate conversion factor was applied to calculate the neutron absorbed dose rate in the detector.

To convert the neutron fluence per source particle to neutron flux, the neutron production rate of the source must be known. The source neutron production rate was determined according to the following equation:

$$
N\left(\frac{\text { neutrons }}{\sec }\right)=\phi_{P}\left(\frac{\#}{\mathrm{~cm}^{2}-\mathrm{sec}-\text { watt }}\right) * P(W) * A\left(\mathrm{~cm}^{2}\right)
$$

where

$\mathbf{N}=$ the source neutron production rate

$\phi_{\mathrm{p}}=$ the neutron flux per unit power

$P=$ power for the minimum critical accident of concern

$A=$ the surface area of the detector sphere $(r=2 m)$

Because the criticality accident sources used in this analysis have differing levels of moderation and ${ }^{235} \mathrm{U}$ enrichments, different power levels and neutron spectra correspond to the minimum accident of concern. Using the appropriate values for $\phi_{p}$ and $\mathrm{P}$ from POEF- 
SH-31, the neutron source rates for each source term were calculated. The neutron source rate corresponding to the $20 \%{ }^{235} \mathrm{U}$ enriched source term, $\mathrm{S} 1$ and $\mathrm{S} 3$, is $5.202 \times 10^{13} \mathrm{n} / \mathrm{s}$. The neutron source rate corresponding to the $100 \%{ }^{235} \mathrm{U}$ enriched source term, $\mathrm{S} 2$, is $5.467 \times 10^{13} \mathrm{n} / \mathrm{s}$. It should be noted that these neutron sources are based on the Henderson Flux to Dose Conversion Factors in POEF-SH-31 and should not be used with any other response function.

A neutron flux to neutron absorbed dose rate conversion factor was applied to the neutron flux to calculate the neutron absorbed dose rate. In this analysis, the neutron absorbed dose rate was calculated on a per energy bin basis. The absorbed dose rate at the detector was calculated using the following equation:

$$
D\left(\frac{m r a d}{h r}\right)=\sum_{i=1}^{27} N\left(\frac{n}{s}\right) * \phi_{i, m c m a}\left(\frac{\frac{\#}{c m^{2}}}{n}\right) * k_{i}\left(\frac{\frac{r a d}{n}}{c m^{2}}\right) *\left(\frac{3600 \mathrm{sec}}{h r}\right) *\left(\frac{1000 \mathrm{mrad}}{r a d}\right)
$$

where

$$
\begin{array}{ll}
\mathrm{D}= & \begin{array}{l}
\text { neutron absorbed dose rate at detector } \\
\text { the neutron fluence per source particle at } \\
\phi_{\mathrm{i}, \text { menp }}=
\end{array} \\
\mathrm{N}= & \begin{array}{l}
\text { detector } \\
\text { source neutron production rate }
\end{array} \\
\mathrm{k}= & \text { neutron flux to neutron absorbed dose rate conversion factor } \\
\mathrm{i}= & \text { energy bin index }
\end{array}
$$

In this analysis, the Henderson Free in Air flux to dose conversion factors, as shown in Table 3, were used. 
Table 3. Henderson Free-in-Air Flux-to-Dose Conversion Factors

\begin{tabular}{|c|c|}
\hline Upper Energy Boundary (MeV) & $\begin{array}{l}\text { Henderson Free in Air Flux-to-Dose } \\
\text { Conversion Factor (rads/(n/cm^2)) }\end{array}$ \\
\hline $1.00 \mathrm{E}-11$ & $0.00 \mathrm{E}+00$ \\
\hline $1.00 \mathrm{E}-08$ & $6.03 E-17$ \\
\hline $3.00 \mathrm{E}-08$ & $2.46 \mathrm{E}-16$ \\
\hline $5.00 \mathrm{E}-08$ & $3.69 \mathrm{E}-16$ \\
\hline $1.00 \mathrm{E}-07$ & $6.52 \mathrm{E}-16$ \\
\hline $2.25 \mathrm{E}-07$ & $1.40 \mathrm{E}-15$ \\
\hline $3.25 \mathrm{E}-07$ & $2.54 \mathrm{E}-15$ \\
\hline $4.00 \mathrm{E}-07$ & $3.37 \mathrm{E}-15$ \\
\hline $8.00 \mathrm{E}-07$ & $5.39 \mathrm{E}-15$ \\
\hline $1.00 \mathrm{E}-06$ & $8.37 E-15$ \\
\hline $1.13 \mathrm{E}-06$ & $9.93 \mathrm{E}-15$ \\
\hline $1.30 \mathrm{E}-06$ & $1.13 \mathrm{E}-14$ \\
\hline $1.77 \mathrm{E}-06$ & $1.42 \mathrm{E}-14$ \\
\hline $3.05 \mathrm{E}-06$ & $2.20 \mathrm{E}-14$ \\
\hline $1.00 \mathrm{E}-05$ & $5.46 \mathrm{E}-14$ \\
\hline $3.00 \mathrm{E}-05$ & $1.70 \mathrm{E}-13$ \\
\hline $1.00 \mathrm{E}-04$ & $5.43 \mathrm{E}-13$ \\
\hline $5.50 \mathrm{E}-04$ & $2.36 \mathrm{E}-12$ \\
\hline 3.00E-03 & $1.35 \mathrm{E}-11$ \\
\hline $1.70 \mathrm{E}-02$ & $7.20 \mathrm{E}-11$ \\
\hline $1.00 \mathrm{E}-01$ & $3.12 \mathrm{E}-10$ \\
\hline $4.00 \mathrm{E}-01$ & $1.08 \mathrm{E}-09$ \\
\hline $9.00 \mathrm{E}-01$ & 1.79E-09 \\
\hline $1.40 \mathrm{E}+00$ & $2.44 \mathrm{E}-09$ \\
\hline $1.85 \mathrm{E}+\infty 0$ & 2.79E-09 \\
\hline $3.00 \mathrm{E}+00$ & $3.22 \mathrm{E}-09$ \\
\hline $6.43 \mathrm{E}+00$ & $4.18 \mathrm{E}-09$ \\
\hline $2.00 \mathrm{E}+01$ & 4.72E-09 \\
\hline
\end{tabular}




\subsection{RESULTS}

In this analysis, a source was placed at one of the three source locations, as shown in Figure 7, and the detector response for each individual detector (at both the $1 \mathrm{~m}$ and $5 \mathrm{~m}$ heights) was calculated in turn. A complete MCNP input file for one of the source locations is included in Appendix A. The fluence per source neutron values calculated by MCNP at the detector locations were converted to absorbed dose rates using the methodology presented in section 3.5. These calculations are also included in Appendix B.

The detector responses for each source location (S1, S2, and S3) and for each detector height are presented in Tables 4 through 6 , respectively. The detectors are identified by the number of the column on which they are mounted. As a result of the large thicknesses of material between the source and the detectors, only the detectors nearest the source yielded a statistically significant response for the computer time used.

Table 4. Detector Response of Four Detectors Nearest S1 (the South Source)

\begin{tabular}{|c|c|c|c|c|}
\hline \multirow[b]{2}{*}{$\begin{array}{l}\text { Detector Location } \\
\text { (Column Number) }\end{array}$} & \multicolumn{2}{|c|}{ Current Height } & \multicolumn{2}{|c|}{1 Meter Height } \\
\hline & $\begin{array}{l}\text { Detector } \\
\text { Response } \\
\text { (mrad/hr) }\end{array}$ & $\begin{array}{l}\text { Standard } \\
\text { Deviation } \\
\text { (mrad/hr) }\end{array}$ & $\begin{array}{l}\text { Detector } \\
\text { Response } \\
\text { (mrad/hr) }\end{array}$ & $\begin{array}{l}\text { Standard } \\
\text { Deviation } \\
\text { (mrad/hr) }\end{array}$ \\
\hline $97 \mathrm{E}$ & 374 & 23 & 248 & 19 \\
\hline 97T & 286 & 20 & 144 & 13 \\
\hline $87 \mathrm{E}$ & 52 & 9 & 27 & 6 \\
\hline $87 \mathrm{~S}$ & 38 & 7 & 14 & 5 \\
\hline
\end{tabular}


Table 5. Detector Response of Two Detectors Nearest S2 (the North Source)

\begin{tabular}{|c|c|c|c|c|}
\hline \multirow[b]{2}{*}{$\begin{array}{l}\text { Detector Location } \\
\text { (Column Number) }\end{array}$} & \multicolumn{2}{|c|}{ Current Height } & \multicolumn{2}{|c|}{1 Meter Height } \\
\hline & $\begin{array}{l}\text { Detector } \\
\text { Response } \\
(\mathrm{mrad} / \mathrm{hr})\end{array}$ & $\begin{array}{l}\text { Standard } \\
\text { Deviation } \\
\text { (mrad/hr) }\end{array}$ & $\begin{array}{l}\text { Detector } \\
\text { Response } \\
\text { (mrad/hr) }\end{array}$ & $\begin{array}{l}\text { Standard } \\
\text { Deviation } \\
\text { (mrad/hr) }\end{array}$ \\
\hline $7 S$ & 179 & 20 & 111 & 15 \\
\hline $7 \mathrm{E}$ & 156 & 19 & 153 & 19 \\
\hline
\end{tabular}

Table 6. Detector Response of Four Detectors Nearest S3 (the Middle Source)

\begin{tabular}{|c|c|c|c|c|}
\hline \multirow[b]{2}{*}{$\begin{array}{l}\text { Detector Location } \\
\text { (Column Number) }\end{array}$} & \multicolumn{2}{|c|}{ Current Height } & \multicolumn{2}{|c|}{1 Meter Height } \\
\hline & $\begin{array}{l}\text { Detector } \\
\text { Response } \\
\text { (mrad/hr) }\end{array}$ & $\begin{array}{l}\text { Standard } \\
\text { Deviation } \\
\text { (mrad/hr) }\end{array}$ & $\begin{array}{l}\text { Detector } \\
\text { Response } \\
\text { (mrad/hr) }\end{array}$ & $\begin{array}{l}\text { Standard } \\
\text { Deviation } \\
\text { (mrad/hr) }\end{array}$ \\
\hline $27 \mathrm{~S}$ & 93 & 12 & 33 & 7 \\
\hline $27 \mathrm{E}$ & 79 & 11 & 51 & 9 \\
\hline $47 \mathrm{~S}$ & 55 & 9 & 22 & 5 \\
\hline $48 \mathrm{E}$ & 54 & 9 & 40 & 9 \\
\hline
\end{tabular}




\subsection{DISCUSSION}

In the MCNP analysis, detectors were modeled at both the current height of the CAAS detectors and at their proposed new height of $1 \mathrm{~m}$. For a given source location, detector responses were calculated in all detectors, at both the current and new heights. If, for a given detector location (column number), the response in both the higher and lower position was sufficient to result in an alarm, then detector coverage was maintained for the new detector location. If, however, the response in the higher position was sufficient to cause an alarm and the response in the lower position was not, then inadequate coverage would be provided by detectors at the proposed new locations.

Statistically significant detector responses were only obtained for those detectors nearest the source. This, for the most part, is due to the immense size of the $\mathrm{X}-326$ building and the fact that it contains a large number of process cells. This results in great distances and large amounts of homogenized process cell between the source and detectors in the building model. As a consequence, detector response decreases rapidly with distance from the source. Another major reason for the limited detector response is the variance reduction and computation time used in the MCNP calculation. In order to provide the most accurate values of detector response, no variance reduction was employed. As a result large computation times were encountered. Unreasonable computation time would be required to obtain statistically significant responses in detectors more than three or four rows of process cells from the source.

Instead of increasing the computation time to unreasonable lengths of time, detector responses were calculated for several bounding cases and then symmetry arguments were applied to show that sufficient coverage exists in the remainder of the building. For the first source, S1, detector responses for detectors on columns 97E, 97T, 87E, and 87S indicate that lowering the detectors will not result in a loss of coverage. Source and detector 
locations are shown in Figure 7. Similarly for the north end of the building, the response to source $S 2$ in detectors located on columns $7 \mathrm{~S}$ and $7 \mathrm{E}$ indicate that lowering the detectors will not result in a loss of coverage. This indicates that criticality coverage in the north and south end of the building will be maintained if the CAAS detectors are lowered. Due to the symmetry of the units and the detectors in the middle of the building (units X-27-2, X-27-3 and X-25-1 through 6) a source placed in the center of the detectors located on columns 27E, $27 \mathrm{~S}, 48 \mathrm{E}$, and $47 \mathrm{~S}$ (in unit $\mathrm{X}-25-1$ ) will provide a result that will be representative of the remaining units and detectors in the middle of the building. For example, if a source were to be located in the center of the detectors on columns 48E, 47S, 67E, and 67S (see Figure $7)$, the geometrical arrangement of process cells and detectors around the source will be nearly identical to the case analyzed. The only difference is that one of the detectors may actually be closer to the source. This is because the case analyzed was a bounding case for shielding and distance between the source and the detector. As a result of this symmetry, any other criticality accident location will result in detector responses as high or higher than those calculated in the case analyzed. The calculated detector responses for this source, S3, also indicate that lowering the detectors will not result in a loss of coverage. Due to symmetry, this result can be applied to the other units in the center of the building. Therefore, lowering the detectors will not result in a loss of criticality coverage on the cell floor of the X-326 building. 
POEF-SH-34

\subsection{CONCLUSION}

The criticality alarm detectors at the PORTS facility are set to alarm at a neutron absorbed dose rate value of $5 \mathrm{mrad} / \mathrm{hr}$. As can be seen from the calculated absorbed dose rates presented in Tables 4 through 6, all of the detectors that alarm for the given criticality event at their current height in the process building will also alarm if located at a height of $1 \mathrm{~m}$. This includes minimum accidents of concern spanning enrichments from 10 to $100 \%$ ${ }^{235} \mathrm{U}$. Therefore, lowering the detectors will not result in a loss of coverage. 


\subsection{REFERENCES}

1. Negron, S. B. and R. W. Tayloe, Jr., "Analysis of the Proposed Relocation of the Neutron Criticality Clusters in the Process Buildings for the Portsmouth Gaseous Diffusion Plant", POEF-SH-12, Martin Marietta Utility Services, Inc., January 1994.

2. Portsmouth Gaseous Diffusion Plant Final Safety Analysis Report, Volume 1, GAT/GDP-1073, Martin Marietta Energy Systems, Inc., April 1985.

3. Briesmeister, J. (Editor), "MCNP - A General Monte Carlo N-Particle Transport Code", Version 4A, LA-12625-M, (Available from the Radiation Shielding Information Center as Code Package CCC-200), November 1993.

4. Westfall, R. M. and J. R. Knight, "Radiation Levels in a Gaseous Diffusion Plant Assuming a Low Enriched Criticality Event Corresponding to the ANSI Standard Minimum Accident of Concern", ORNL/CSD/INF-82-7, January 1983.

5. Van Riper, K. A., "SABRINA User's Guide", LA-UR-93-3696 (Available from the Radiation Shielding Information Center as Code Package PSR-242), October 1993.

6. American National Standard Criticality Accident Alarm System", ANSI/ANS-8.31986, American Nuclear Society, 1986.

7. Lee, B. L., et al., "Calculated In-Air Leakage Spectra and Power Levels for the ANSI Standard Minimum Accident of Concern, " POEF-SH-31, Martin Marietta Utility Services, Inc., June, 1995.

8. "X-Site Radiation Alarm System Plot Plan Cable Routing," ORNL Drawing No. DX220J-2E, 1986.

9. Jones, S.A., "Replacement GDP Cluster Placement", Goodyear Atomic Corporation Internal Correspondence, GAT-521-86-22, February, 1986.

10. "South Half Ground Floor Plan - Unit X-25-3 thru Purge and Product," Drawing No. X-325-9A, Portsmouth Gaseous Diffusion Plant, 1956.

11. "North Half Ground Floor Plan - Unit X-27-1 thru 3 and Units X-25-1, X-25-2" Drawing No. X-326-8A, Portsmouth Gaseous Diffusion Plant, 1956.

12. "South Half Cell Floor Plan Unit X-25-3 thru 7 Purge and Product," Drawing No. X326-11a, 1956. 
POEF-SH-34

13. "North Half Cell Floor Plan Unit X-27-1 thru 3 and Units X-25-1, X-25-1," ORNL Drawing No. X-325-10A, 1958.

14. "1/16" Scale Section," Drawing No. X-326-18A, 1956.

15. "Cell Housing Floor Plan - Units X-27-1 thru 3 and X-25-1 and X-25-2" Drawing No. X-326-2000A, 1962.

16. Cell Housing Floor Plant - Unit X-25-3 thru 7; Purge Cascade," Drawing No. X-3262001A, 1962. 
POEF-SH-34

Appendix A - MCNP Input File 
This is a model of building $\times 326$

$c$ by $c$ and $j \quad 4-4-95$

$c$

c

$10 \quad 4 \quad 1.6021 E-3 \quad 20 \quad-30 \quad 210 \quad-230 \quad 732 \quad-742$ imp: $n=1 \quad u=2 \$$

$20 \quad 4 \quad 1.6021 E-3 \quad 40 \quad-50 \quad 210 \quad-230 \quad 732 \quad-742$ imp:n=1 u=2 s

$\begin{array}{lllllllll}30 & 4 & 1.6021 E-3 & 20 & -30 & 260 & -280 & 732 & -742 \text { imp:n=1 u=2 S }\end{array}$

$\begin{array}{llllllllll}40 & 4 & 1.6021 E-3 & 40 & -50 & 260 & -280 & 732 & -742 \text { imp:n=1 } u=2 s\end{array}$

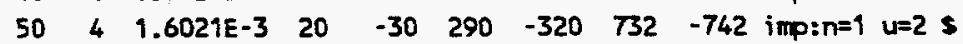

$60 \quad 4 \quad 1.6021 E-3 \quad 40 \quad-50 \quad 290 \quad-320 \quad 732 \quad-742$ imp:n=1 u=2 s

$\begin{array}{lllllllll}70 & 4 & 1.6021 E-3 & 20 & -30 & 330 & -360 & 732 & -742 \text { imp:n=1 u=2 s }\end{array}$

$80 \quad 4 \quad 1.6021 E-3 \quad 40 \quad-50 \quad 330 \quad-360 \quad 732 \quad-742$ imp:n=1 u=2 s

$90 \quad 4 \quad 1.6021 E-3 \quad 20 \quad-30 \quad 370 \quad-390 \quad 732 \quad-742$ imp:n=1 $u=2 \$$

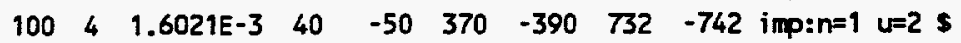

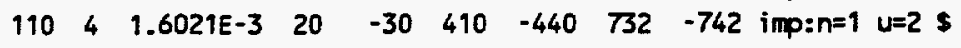

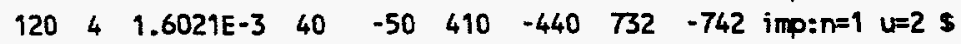

$\begin{array}{lllllllll}130 & 4 & 1.6021 E-3 & 20 & -30 & 450 & -480 & 732 & -742 \text { imp:n=1 u=2 \& }\end{array}$

$\begin{array}{lllllllll}140 & 4 & 1.6021 E-3 & 40 & -50 & 450 & -480 & 732 & -742 \text { imp:n=1 u=2 s }\end{array}$

$\begin{array}{llllllllll}150 & 4 & 1.6021 E-3 & 20 & -30 & 490 & -520 & 732 & -742 \text { imp:n=1 u=2 s }\end{array}$

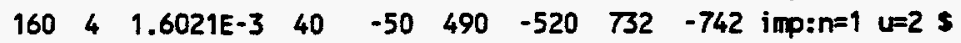

$\begin{array}{llllllllll}170 & 4 & 1.6021 E-3 & 20 & -30 & 540 & -560 & 732 & -742 \text { imp:n=1 u=2 s }\end{array}$

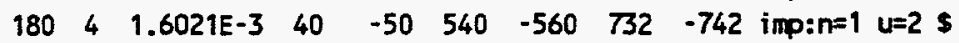

$190 \quad 4 \quad 1.6021 E-3 \quad 20 \quad-30 \quad 580 \quad-600 \quad 732 \quad-742$ imp:n=1 u=2 s

$2004 \quad 1.6021 E-3 \quad 40 \quad-50 \quad 580 \quad-600 \quad 732 \quad-742$ imp: $n=1 \quad u=2$ s

$\left.\begin{array}{lllllllll}210 & 1 & 4.354 E-5 & (13 & -63 & 203 & -613 & 732 & -742\end{array}\right)$

$((203-210):(230-260):(280-290):(320-330)$

$:(360-370):(390-410):(440-450):(480-490)$

$:(520-540):(560-580):(600-613):(13-20)$

$:(30-40):(50-63))$

imp:n=1 $u=2$ \& air around process equipment (repeated struc)

$\begin{array}{llllllll}300 & 0 & -62 & 12 & -612 & 202 & -741 & 731\end{array}$

lat $=1$ u=1 imp:n=1 fill $=0: 8 \quad 0: 0 \quad 0: 0$

$28 r$

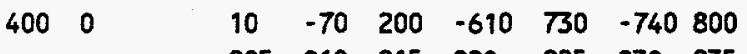

$\begin{array}{lllllll}805 & 810 & 815 & 820 & 825 & 830 & 835\end{array}$

840845 imp: $n=1 \quad$ fill $=1$

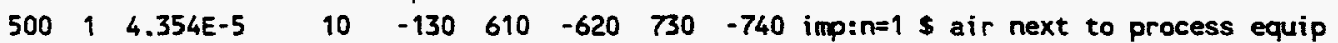

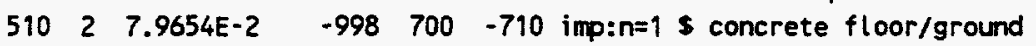

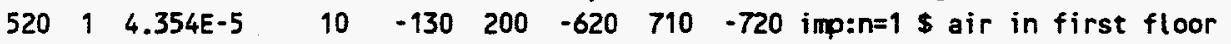

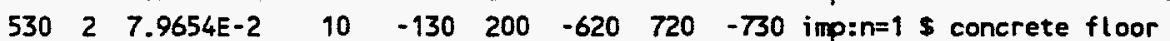

$\begin{array}{lllllllll}540 & 1 & 4.354 E-5 & 10 & -130 & 200 & -620 & 740 & -750\end{array}$

$\begin{array}{llllllll}860 & 865 & 870 & 875 & 880 & 885 & 890 & 895\end{array}$

$900905910915 \quad$ imp: $n=1$ \$ air above process equip

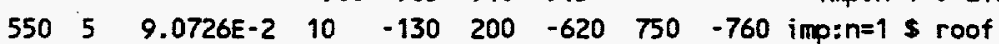

$\begin{array}{llllllllll}600 & 4 & 1.6021 E-3 & 80 & -90 & 210 & -230 & 730 & -740 \text { imp:n=1 \$ }\end{array}$

$\begin{array}{llllllllll}610 & 4 & 1.6021 E-3 & 100 & -120 & 220 & -240 & 730 & -740 & \text { imp:n=1 \$ }\end{array}$

$\begin{array}{rlllllllll}620 & 4 & 1.6021 E-3 & 80 & -90 & 260 & -280 & 730 & -740 & \text { imp:n=1 } \$\end{array}$

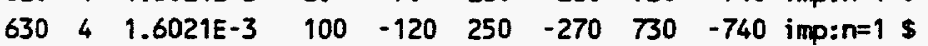

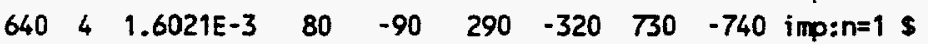

$\begin{array}{llllllllll}650 & 4 & 1.6021 E-3 & 110 & -120 & 300 & -310 & 730 & -740 & \text { imp: } n=1\end{array}$

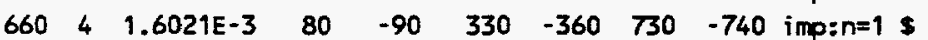

$\begin{array}{llllllllll}670 & 4 & 1.6021 E-3 & 110 & -120 & 340 & -350 & 730 & -740 & \text { imp: } n=1\end{array}$

$\begin{array}{llllllllll}680 & 4 & 1.6021 E-3 & 80 & -90 & 370 & -390 & 730 & -740 & \text { imp: } n=1\end{array}$

$\begin{array}{llllllllll}690 & 4 & 1.6021 E-3 & 110 & -120 & 380 & -400 & 730 & -740 & \text { imp:n=1 s }\end{array}$

$\begin{array}{llllllllll}700 & 4 & 1.6021 E-3 & 80 & -90 & 410 & -440 & 730 & -740 & \text { imp: } n=1\end{array}$

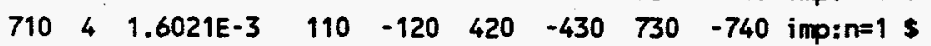

$\begin{array}{llllllllll}720 & 4 & 1.6021 E-3 & 80 & -90 & 450 & -480 & 730 & -740 & \text { imp:n=1 } s\end{array}$

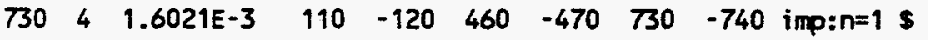

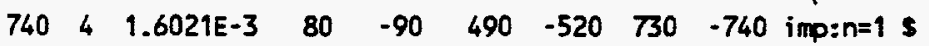

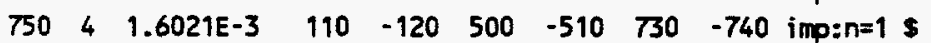

$\begin{array}{llllllllll}760 & 4 & 1.6021 E-3 & 80 & -90 & 540 & -560 & 730 & -740 & \text { imp:n=1 \$ }\end{array}$

$\begin{array}{llllllllll}770 & 4 & 1.6021 E-3 & 100 & -120 & 530 & -550 & 730 & -740 & \text { imp:n=1 s }\end{array}$

$\begin{array}{llllllllll}780 & 4 & 1.6021 E-3 & 80 & -90 & 580 & -600 & 730 & -740 & \text { imp:n=1 \$ }\end{array}$

790 4. $1.6021 E-3 \quad 100 \quad-120 \quad 570 \quad-590 \quad 730 \quad-740 \quad 855$ imp:n=1 \&

$\left.\begin{array}{lllllllll}800 & 1 & 4.354 E-5 & (70 & -90 & 200 & -610 & 730 & -740\end{array}\right)$

$((200-210):(230-260):(280-290):(320-330):$ 


\begin{tabular}{|c|c|c|c|c|c|c|c|}
\hline \multirow[t]{4}{*}{810} & \multirow[t]{4}{*}{1} & $4.354 E-5$ & \multicolumn{2}{|c|}{$((200-220):(240-250):(270-300):(310-340):$} & \multicolumn{3}{|c|}{$-740850855)$} \\
\hline & & & \multicolumn{5}{|c|}{$(350-380):(400-420):(430-460):(470-500):$} \\
\hline & & & \multirow{2}{*}{$\begin{array}{l}510 \\
(100\end{array}$} & $-530):(550-570)=(590$ & $-610):(90-$ & \multicolumn{2}{|l|}{$-100):$} \\
\hline & & & & $-110270-530):(120-1$ & -130)) imp: $n=$ & \multirow{2}{*}{\multicolumn{2}{|c|}{ \$ air around process }} \\
\hline \multirow[t]{2}{*}{900} & \multirow[t]{2}{*}{1} & $4.354 E-5$ & \multicolumn{3}{|c|}{$((-10: 130:-200: 620) 710-998):$} & & \\
\hline & & & $८(10$ & 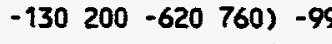 & 298) imp: $n=1$ & S air around b & building \\
\hline 910 & 0 & & (998 & $-999700):(-999-700)$ & imp: $n=1$ & S internal voi & bid \\
\hline 920 & 1 & $4.354 E-5$ & -800 & & imp: $n=1$ & \$ detector 1 & $L$ \\
\hline 921 & 1 & $4.354 E-5$ & -805 & & $i m p: n=1$ & \$ detector 2 & $L$ \\
\hline 922 & 1 & $4.354 E-5$ & -810 & & imp: $n=1$ & 5 detector 3 & $L$ \\
\hline 923 & 1 & $4.354 E-5$ & -815 & & imp: $n=1$ & $\$$ detector 4 & $\mathbf{L}$ \\
\hline 924 & 1 & $4.354 E-5$ & -820 & & $i m p: n=1$ & $\$$ detector 5 & $\mathbf{L}$ \\
\hline 925 & 1 & $4.354 E-5$ & -825 & & imp: $n=1$ & $\$$ detector 6 & $\mathbf{L}$ \\
\hline 926 & 1 & $4.354 E-5$ & -830 & & imp:n=1 & $\$$ detector 7 & $\mathbf{L}$ \\
\hline 927 & 1 & $4.354 E-5$ & -835 & & imp: $n=1$ & 5 detector 8 & $L$ \\
\hline 928 & 1 & $4.354 E-5$ & -840 & & imp:n=1 & $\$$ detector 9 & $L$ \\
\hline 929 & 1 & $4.354 E-5$ & -845 & & imp: $n=1$ & S detector 10 & $L$ \\
\hline 930 & 1 & $4.354 E-5$ & -850 & & imp: $n=1$ & $\$$ detector 11 & $L$ \\
\hline 931 & 1 & $4.354 E-5$ & -855 & & imp: $n=1$ & $\$$ detector 12 & $L$ \\
\hline 932 & 1 & $4.354 E-5$ & -860 & & imp: $n=1$ & \$ detector 1 & $u$ \\
\hline 933 & 1 & $4.354 E-5$ & -865 & & imp: $n=1$ & \$ detector 2 & $\mathbf{u}$ \\
\hline 934 & 1 & $4.354 E-5$ & -870 & & imp:n=1 & \$ detector 3 & $\mathbf{u}$ \\
\hline 935 & 1 & $4.354 E-5$ & -875 & & imp: $n=1$ & $\$$ detector 4 & $\mathbf{u}$ \\
\hline 936 & 1 & $4.354 E-5$ & -880 & & imp:n=1 & \$ detector 5 & $\mathbf{u}$ \\
\hline 937 & 1 & $4.354 E-5$ & -885 & & imp:n=1 & 5 detector 6 & $\mathbf{u}$ \\
\hline 938 & 1 & $4.354 E-5$ & -890 & & imp: $n=1$ & 5 detector 7 & $u$ \\
\hline 939 & 1 & $4.354 E-5$ & -895 & & imp: $n=1$ & \$ detector 8 & $\mathbf{u}$ \\
\hline 940 & 1 & $4.354 E-5$ & -900 & & imp: $n=1$ & $\$$ detector 9 & 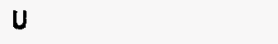 \\
\hline 941 & 1 & $4.354 E-5$ & -905 & & imp: $n=1$ & $\$$ detector 10 & $u$ \\
\hline 942 & 1 & $4.354 E-5$ & -910 & & imp: $n=1$ & \$ detector 11 & $u$ \\
\hline 943 & 1 & $4.354 E-5$ & -915 & & imp:n=1 & $\$$ detector 12 & $U$ \\
\hline 999 & 0 & 999 & & imp: $n=0$ & & S external voic & \\
\hline
\end{tabular}

$\begin{array}{llll}10 & \text { px } & 0.0 & \$ \text { north end of building } \\ 12 & \text { px } & -0.001 & \$ \\ 13 & \text { px } & -0.01 & \$ \\ 20 & \text { px } & 686.0 & \$ \\ 30 & \text { px } & 3338.0 & \$ \\ 40 & \text { px } & 4161.0 & \$ \\ 50 & \text { px } & 6812.0 & \$ \\ 62 & \text { px } & 6888.001 & \$ \\ 63 & \text { px } & 6888.01 & \$ \\ 70 & \text { px } & 61992.0 & \$ \\ 80 & \text { px } & 62678.0 & \$ \\ 90 & \text { px } & 65339.0 & \$ \\ 100 & \text { px } & 66101.0 & \$ \\ 110 & \text { px } & 66162.0 & \$ \\ 120 & \text { px } & 67564.0 & \$ \\ 130 & \text { px } & 69494.0 & \$ \text { south face of building } \\ 200 & \text { py } & 0.0 & \$ \text { west face of building } \\ 202 & \text { py } & -0.001 & \$ \\ 203 & \text { py } & -0.01 & \$ \\ 210 & \text { py } & 796.0 & \$ \\ 220 & \text { py } & 823.0 & \$ \\ 230 & \text { py } & 1825.0 & \$ \\ 240 & \text { py } & 1829.0 & \$ \\ 250 & \text { py } & 2255.0 & \$ \\ 260 & \text { py } & 2259.0 & \$ \\ 270 & \text { py } & 3261.0 & \$ \\ 280 & \text { py } & 3288.0 & \$ \\ 290 & \text { py } & 3722.0 & \$ \\ 300 & \text { py } & 3780.0 & \$ \\ 310 & \text { py } & 4694.0 & \$ \\ 320 & \text { py } & 4751.0 & \$\end{array}$




\begin{tabular}{|c|c|c|c|c|c|c|c|}
\hline 330 & py & \multicolumn{2}{|c|}{5185.0} & \multicolumn{4}{|l|}{$s$} \\
\hline 340 & py & \multicolumn{2}{|c|}{5243.0} & \multicolumn{4}{|l|}{$\$$} \\
\hline 350 & py & \multicolumn{2}{|c|}{6157.0} & \multicolumn{4}{|l|}{$s$} \\
\hline 360 & py & \multicolumn{2}{|c|}{6214.0} & \multicolumn{4}{|l|}{ s } \\
\hline 370 & py & \multicolumn{2}{|c|}{6648.0} & \multicolumn{4}{|l|}{ s } \\
\hline 380 & py & \multicolumn{2}{|c|}{6675.0} & \multicolumn{4}{|l|}{$\$$} \\
\hline 390 & py & 7677. & & $\$$ & & & \\
\hline 400 & py & $\pi 742$. & & $s$ & & & \\
\hline 410 & Py & 8111. & & $\$$ & & & \\
\hline 420 & py & 8138. & & $\$$ & & & \\
\hline 430 & py & 9083. & & $\$$ & & & \\
\hline 440 & py & 9140. & & $\$$ & & & \\
\hline 450 & py & 9574. & & $\$$ & & & \\
\hline 460 & py & 9601. & & $\$$ & & & \\
\hline 470 & py & 10516 & & $\$$ & & & \\
\hline 480 & py & 10603 & & $\$$ & & & \\
\hline 490 & py & 11037 & & $\$$ & & & \\
\hline 500 & py & 11064 & & $\$$ & & & \\
\hline 510 & py & 11979 & & $\$$ & & & \\
\hline 520 & py & 12066 & & $\$$ & & & \\
\hline 530 & py & 12497 & & $\$$ & & & \\
\hline 540 & py & 12500 & & $\$$ & & & \\
\hline 550 & py & 13472 & & $\$$ & & & \\
\hline 560 & py & 13529 & & $\$$ & & & \\
\hline 570 & py & 13929 & & $\$$ & & & \\
\hline 580 & py & 13963 & & $\$$ & & & \\
\hline 590 & py & 14905 & & $\$$ & & & \\
\hline 600 & py & 14992 & & $\$$ & & & \\
\hline 610 & py & 15362 & & $\$$ & & & \\
\hline 612 & py & 15362 & .001 & $\$$ & & & . \\
\hline 613 & py & 15362 & .01 & $\$$ & & & \\
\hline 620 & py & 16825 & & $\$$ east face & of bui & ilding & \\
\hline 700 & pz & -100 & & $\$$ botton of & concre & ete groun & ind \\
\hline 710 & pz & 0.0 & & $\$$ top of con & crete & ground & \\
\hline 720 & pz & 651.0 & & \$ ceiling of & first & floor & \\
\hline 730 & pz & 671.0 & & s top of con & crete & cell fl & (oor) \\
\hline 731 & pz & 670.9 & & $\$$ top of con & crete & ccell fl & (oor) \\
\hline 732 & pz & 670.9 & & $\$$ & & & \\
\hline 740 & $p z$ & 1011. & & $\$$ top of pro & cess $c$ & cells & \\
\hline 741 & pz & 1011. & 001 & $\$$ top of pro & cess c & cells & \\
\hline 742 & pz & 1011. & & $\$$ & & & \\
\hline 750 & pz & 1883 & & $\$$ botton of & roof & & \\
\hline 760 & pz & 1893. & & $\$$ top of roo & & & \\
\hline 800 & s & 4084 & 5121 & 77150.0 & $\$ d$ & detector & $1 \mathrm{~L}$ \\
\hline 805 & s & 4084 & 13899 & 77150.0 & $\$ d$ & detector & $2 L$ \\
\hline 810 & s & 17861 & 5121 & 77150.0 & $\$ d$ & detector & 31 \\
\hline 815 & $\mathbf{s}$ & 17861 & 13899 & 77150.0 & $\$ d$ & detector & $4 L$ \\
\hline 820 & s & 31638 & 5121 & 77150.0 & $\$ d$ & detector & $5 \mathrm{~L}$ \\
\hline 825 & $\mathbf{s}$ & 32339 & 13899 & 77150.0 & $\$ d$ & detector & $6 \mathrm{~L}$ \\
\hline 830 & $\mathbf{s}$ & 45415 & 5121 & 77150.0 & $\$ d$ & detector & $7 \mathrm{~L}$ \\
\hline 835 & s & 45415 & 13899 & 77150.0 & $\$ d$ & detector & $8 \mathrm{~L}$ \\
\hline 840 & $s$ & 59192 & 5121 & 77950.0 & $\$ d$ & detector & $9 \mathrm{~L}$ \\
\hline 845 & $\mathbf{s}$ & 59192 & 13899 & 77150.0 & $s d$ & detector & $10 \mathrm{~L}$ \\
\hline 850 & s & 66081 & 4389 & 77150.0 & $\$ d$ & detector & $11 \mathrm{~L}$ \\
\hline 855 & s & 66081 & 13899 & 77150.0 & $\$ d$ & detector & $12 \mathrm{~L}$ \\
\hline 860 & s & 4084 & 5921 & 117150.0 & $\$$ & detector & $r 1 \mathrm{~L}$ \\
\hline 865 & $\mathbf{s}$ & 4084 & 13899 & 117150.0 & $\$$ & detector & $r 2 L$ \\
\hline 870 & s & 17861 & 5121 & 117150.0 & $\$$ & detector & r $3 L$ \\
\hline 875 & s & 17861 & 13899 & 117150.0 & $\$$ & detector & $14 \mathrm{~L}$ \\
\hline 880 & $\mathbf{s}$ & 31638 & 5121 & 117150.0 & s & detector & r $5 \mathrm{~L}$ \\
\hline 885 & s & 32339 & 13899 & 117150.0 & $\$$ & detector & r $6 \mathrm{~L}$ \\
\hline 890 & $\mathbf{s}$ & 45415 & 5121 & 117150.0 & $\$$ & detector & $r 7 \mathrm{~L}$ \\
\hline 895 & s & 45415 & 13899 & 117150.0 & $\$$ & detector & r $8 \mathrm{~L}$ \\
\hline 900 & s & 59192 & 5121 & 117150.0 & $\$$ & detector & r $9 \mathrm{~L}$ \\
\hline 905 & s & 59192 & 13899 & 117150.0 & $\$$ & detector & $10 \mathrm{~L}$ \\
\hline 910 & $\mathbf{s}$ & 66081 & 4389 & 117150.0 & s & detector & r 11 \\
\hline 915 & $\mathbf{s}$ & 66081 & 13899 & 117150.0 & $\$$ & detector & $r 12$ \\
\hline
\end{tabular}




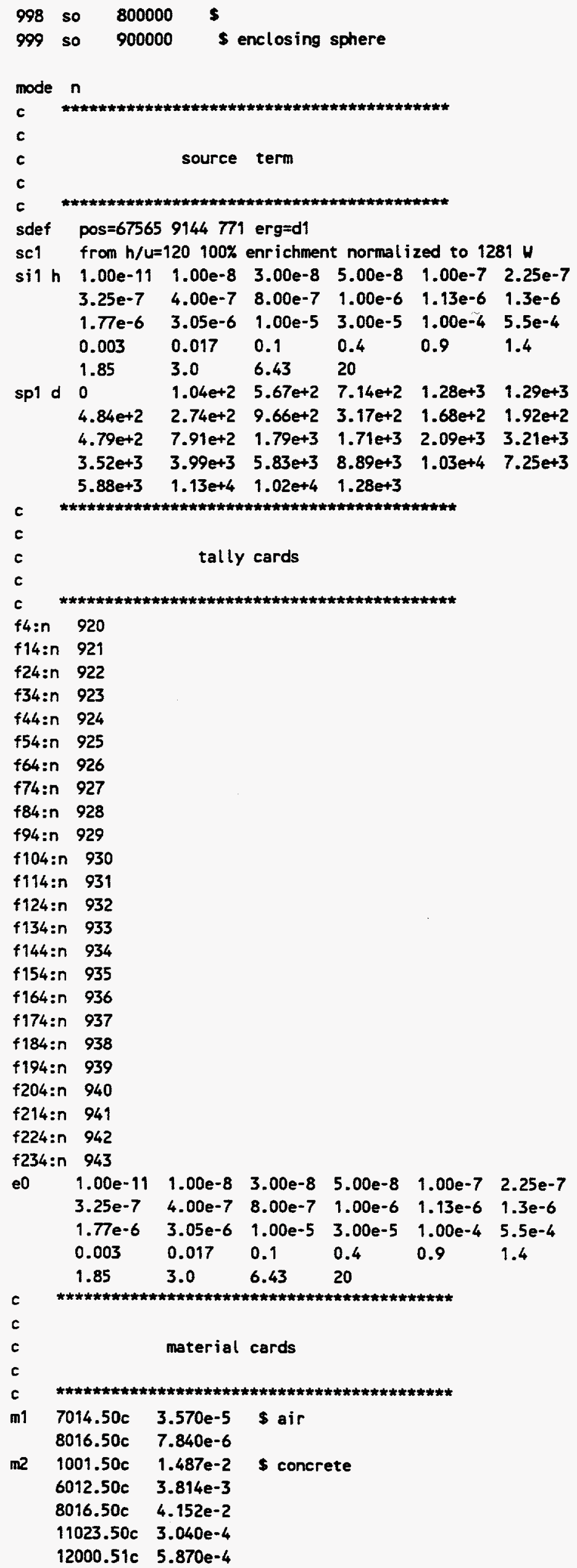




\begin{tabular}{|c|c|c|c|}
\hline & 13027.50e & $7.350 e-4$ & \\
\hline & $14000.50 c$ & $6.037 e-3$ & \\
\hline & $20000.51 c$ & $1.159 e-2$ & \\
\hline & $26000.50 c$ & $1.968 \mathrm{e}-4$ & \\
\hline \multirow[t]{2}{*}{ m3 } & $6012.50 \mathrm{e}$ & $3.921 e-3$ & \$ steel \\
\hline & $26000.50 c$ & $8.349 e-2$ & \\
\hline \multirow[t]{10}{*}{$\mathbf{m 4}$} & $6012.50 \mathrm{c}$ & $6.230 e-5$ & \$ homogenized cell material \\
\hline & $9019.50 c$ & $8.880 e-5$ & \\
\hline & $13027.50 c$ & $8.420 e-5$ & \\
\hline & $14000.50 c$ & $1.666 e-5$ & \\
\hline & $17000.50 c$ & $8.880 e-5$ & \\
\hline & $24000.50 c$ & $1.619 e-4$ & \\
\hline & $25055.51 c$ & $1.703 e-5$ & \\
\hline & $26000.50 c$ & $5.934 \mathrm{e}-4$ & \\
\hline & $28000.50 c$ & $4.563 e-4$ & \\
\hline & $29000.50 c$ & $3.273 e-5$ & \\
\hline \multirow[t]{4}{*}{$\mathrm{m} 5$} & $1001.50 e$ & $4.288 e-2$ & $\$$ roof \\
\hline & $6012.50 c$ & $1.812 \mathrm{e} \cdot 2$ & \\
\hline & $8016.50 c$ & $1.896 \mathrm{e}-3$ & \\
\hline & $26000.50 c$ & $2.783 e-2$ & \\
\hline \multicolumn{4}{|c|}{ ctme 720} \\
\hline & dbcn 2j 35 & 361000 & \\
\hline
\end{tabular}


POEF-SH-34

Appendix B - Spreadsheets for Absorbed Dose Rate Calculations 


\begin{tabular}{|c|c|c|c|c|c|c|}
\hline \multicolumn{7}{|c|}{\begin{tabular}{|l|} 
Detector Response for UPPER Detectors in the $\times 326$ Building (South Source) 51 \\
The source is located at the center of the Purge/Product unit along the south edge of the unit
\end{tabular}} \\
\hline \multirow[b]{2}{*}{ Source Rate $(\mathrm{n} / \mathrm{s})$} & $\begin{array}{l}\text { Upper Energy } \\
\text { Boundary (MeV) }\end{array}$ & \multirow[t]{2}{*}{$\begin{array}{l}\text { Henderson Free in Air } \\
\text { Tissue Kerma Factor } \\
\text { (rads } /\left(n / \mathrm{cm}^{\wedge} 2\right) \text { ) }\end{array}$} & $\begin{array}{l}\text { Detector } 12 \\
\text { Neutron Fluence/sp }\end{array}$ & Relative Error & \multirow[t]{2}{*}{$\begin{array}{l}\text { Absorbed Dose } \\
\text { Rate (rads/s) }\end{array}$} & \multirow[t]{2}{*}{ Error } \\
\hline & $1.00 E-11$ & & $0.00 E+00$ & 0 & & \\
\hline $5.47 E+13$ & $1.00 \mathrm{E}-08$ & $6.03 \mathrm{E}-17$ & $5.01 \mathrm{E}-11$ & 0.1929 & $1.6526 \mathrm{E}-13$ & $3.19 \mathrm{E}-14$ \\
\hline $100 \%$ U-235 & $3.00 \mathrm{E}-08$ & $2.46 \mathrm{E}-16$ & $2.41 \mathrm{E}-10$ & 0.0837 & $3.24264 E-12$ & $2.71 E-13$ \\
\hline$H / U=120$ & 5.00E-08 & $3.69 E-16$ & $2.49 \mathrm{E}-10$ & 0.0872 & $5.01987 E-12$ & $4.38 \mathrm{E}-13$ \\
\hline \multirow[t]{8}{*}{$P=1281 \mathrm{~W}$} & $1.00 \mathrm{E}-07$ & $6.52 E-16$ & $4.62 \mathrm{E}-10$ & 0.0639 & $1.64548 \mathrm{E}-11$ & $1.05 \mathrm{E}-12$ \\
\hline & $2.25 \mathrm{E}-07$ & $1.40 \mathrm{E}-15$ & $2.71 E-10$ & 0.0915 & $2.07454 \mathrm{E}-11$ & $1.9 \mathrm{E}-12$ \\
\hline & $3.25 E-07$ & 2.54E-15 & 7.57E-11 & 0.1951 & $1.05106 \mathrm{E}-11$ & $2.05 E-12$ \\
\hline & 4.00E-07 & 3.37E-15 & $2.76 \mathrm{E}-11$ & 0.3278 & $5.09195 E-12$ & $1.67 \mathrm{E}-12$ \\
\hline & 8.00E-07 & 5.39E-15 & $1.5 \mathrm{BE}-10$ & 0.1378 & $4.66465 \mathrm{E}-11$ & $6.43 \mathrm{E}-12$ \\
\hline & $1.00 E-06$ & 8.37E-15 & $3.81 E-11$ & 0.2862 & $1.74529 \mathrm{E}-11$ & 5E-12 \\
\hline & $1.13 \mathrm{E}-06$ & $9.93 E-15$ & $9.49 \mathrm{E}-12$ & 0.4206 & $5.15106 \mathrm{E}-12$ & $2.17 \mathrm{E}-12$ \\
\hline & $1.30 \mathrm{E}-06$ & $1.13 \mathrm{E}-14$ & $1.98 \mathrm{E}-11$ & 0.3868 & $1.22577 \mathrm{E}-11$ & $4.74 E-12$ \\
\hline \multirow[b]{3}{*}{. } & $1.77 \mathrm{E}-06$ & $1.42 \mathrm{E}-14$ & $4.18 E-11$ & 0.2862 & $3.24613 \mathrm{E}-11$ & $9.29 \mathrm{E}-12$ \\
\hline & $3.05 E-06$ & $2.20 \mathrm{E}-14$ & $1.26 \mathrm{E}-10$ & 0.1648 & $1.51596 \mathrm{E}-10$ & $2.5 \mathrm{E}-11$ \\
\hline & $1.00 \mathrm{E}-05$ & $5.46 E-14$ & $1.74 E-10$ & 0.139 & $5.20447 \mathrm{E}-10$ & $7.23 \mathrm{E}-11$ \\
\hline & $3.00 E-05$ & $1.70 \mathrm{E}-13$ & $2.13 \mathrm{E}-10$ & 0.1302 & $1.97531 \mathrm{E}-09$ & $2.57 E-10$ \\
\hline & $1.00 E-04$ & 5.43E-13 & $2.41 E-10$ & 0.1209 & $7.16731 \mathrm{E}-09$ & $8.67 \bar{E}-10$ \\
\hline & 5.5OE-04 & $2.46 \mathrm{E}-12$ & $3.02 \mathrm{E}-10$ & 0.1069 & $4.0569 \mathrm{E}-08$ & $4.34 \bar{E}-09$ \\
\hline & $3.00 \mathrm{E}-03$ & $1.35 \mathrm{E}-11$ & $2.14 \mathrm{E}-10$ & 0.127 & $1.57982 \mathrm{E}-07$ & 2.01E-08 \\
\hline & $1.70 \mathrm{E}-02$ & $7.20 \mathrm{E}-11$ & $2.53 \mathrm{E}-10$ & 0.116 & $9.9738 \mathrm{E}-07$ & $1.16 \mathrm{E}-07$ \\
\hline & $1.00 \mathrm{E}-01$ & $3.12 \mathrm{E}-10$ & $3.05 \mathrm{E}-10$ & 0.1056 & $5.19583 E-06$ & 5.49E-07 \\
\hline & $4.00 E-01$ & 1.08E-09 & $3.46 \mathrm{E}-10$ & 0.0994 & $2.0411 E-05$ & 2.03E-06 \\
\hline & $9.00 \mathrm{E}-01$ & 1.79E-09 & $2.52 \mathrm{E}-10$ & 0.1181 & $2.46902 E-05$ & $2.92 \mathrm{E}-06$ \\
\hline & $1.40 E+00$ & 2.44E-09 & 1.17E-10 & 0.1752 & $1.56229 \mathrm{E}-05$ & $2.74 \mathrm{E}-06$ \\
\hline & $1.85 E+00$ & 2.79E-09 & $6.88 \mathrm{E}-11$ & 0.2237 & 1.0499E-05 & $2.35 \mathrm{E}-06$ \\
\hline & $3.0 O E+00$ & $3.22 \mathrm{E}-09$ & $1.05 \mathrm{E}-10$ & 0.1847 & $1.85248 \mathrm{E}-05$ & 3.42E-06 \\
\hline & $6.43 E+00$ & $4.18 \mathrm{E}-09$ & $3.13 \mathrm{E}-11$ & 0.2757 & $7.14922 \mathrm{E}-06$ & $1.97 \mathrm{E}-06$ \\
\hline & $2.00 E+01$ & $4.72 E-09$ & $2.60 \mathrm{E}-12$ & $\begin{array}{lll}\cdots & 1\end{array}$ & $6.70255 \mathrm{E}-07$ & $6.7 \mathrm{E}-07$ \\
\hline$\ldots \ldots$ & - & (n) & & $\ldots \ldots$ & . & - \\
\hline & & $\ldots \ldots$ & & $\begin{array}{l}\text { Total AD (rad/s) }= \\
\text { Total AD }(\mathrm{mrad} / \mathrm{hr})=\end{array}$ & $\begin{array}{l}0.000103969 \\
374.2885972 \\
\end{array}$ & $\begin{array}{r}6.48 E-06 \\
23.32584\end{array}$ \\
\hline
\end{tabular}




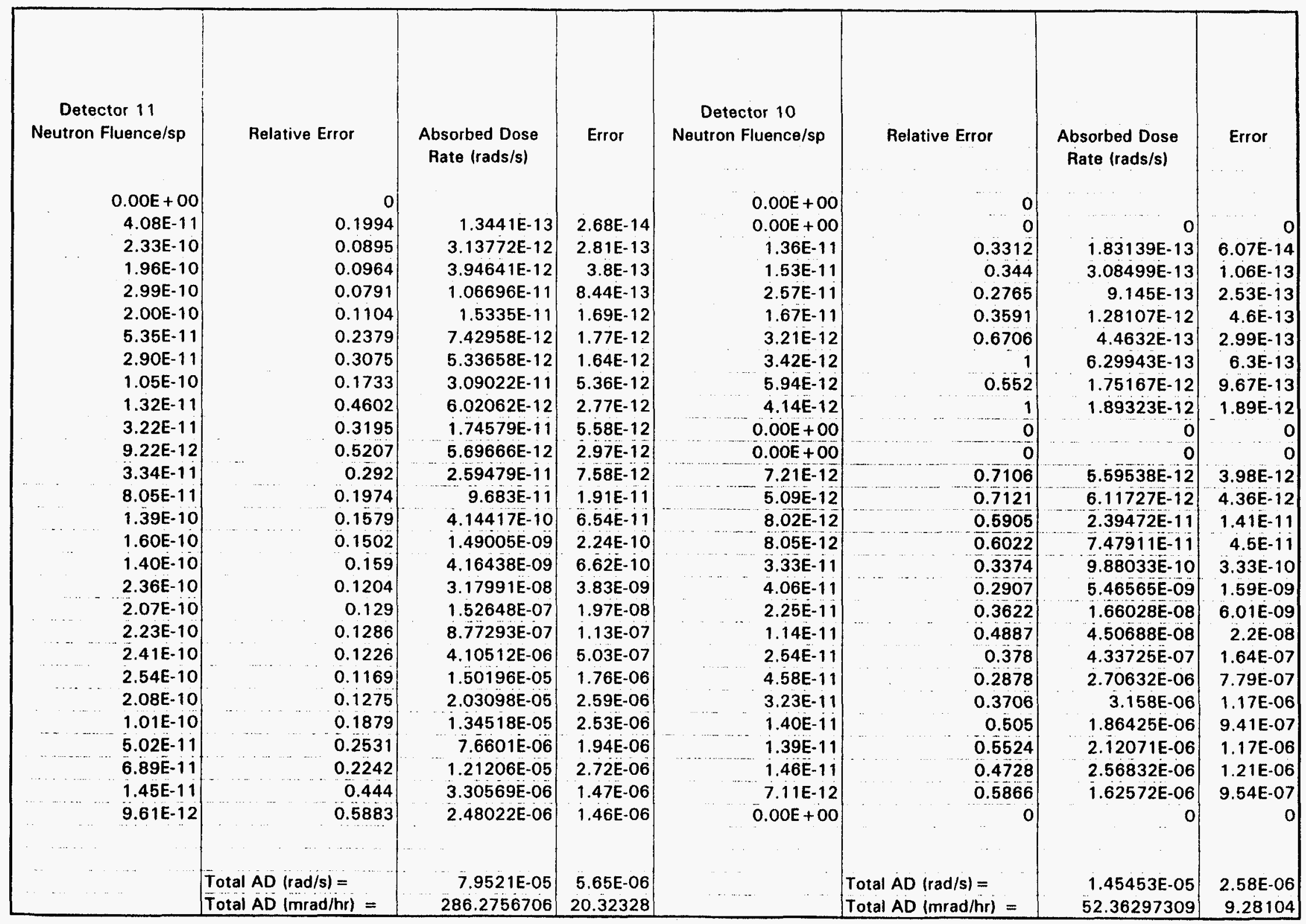




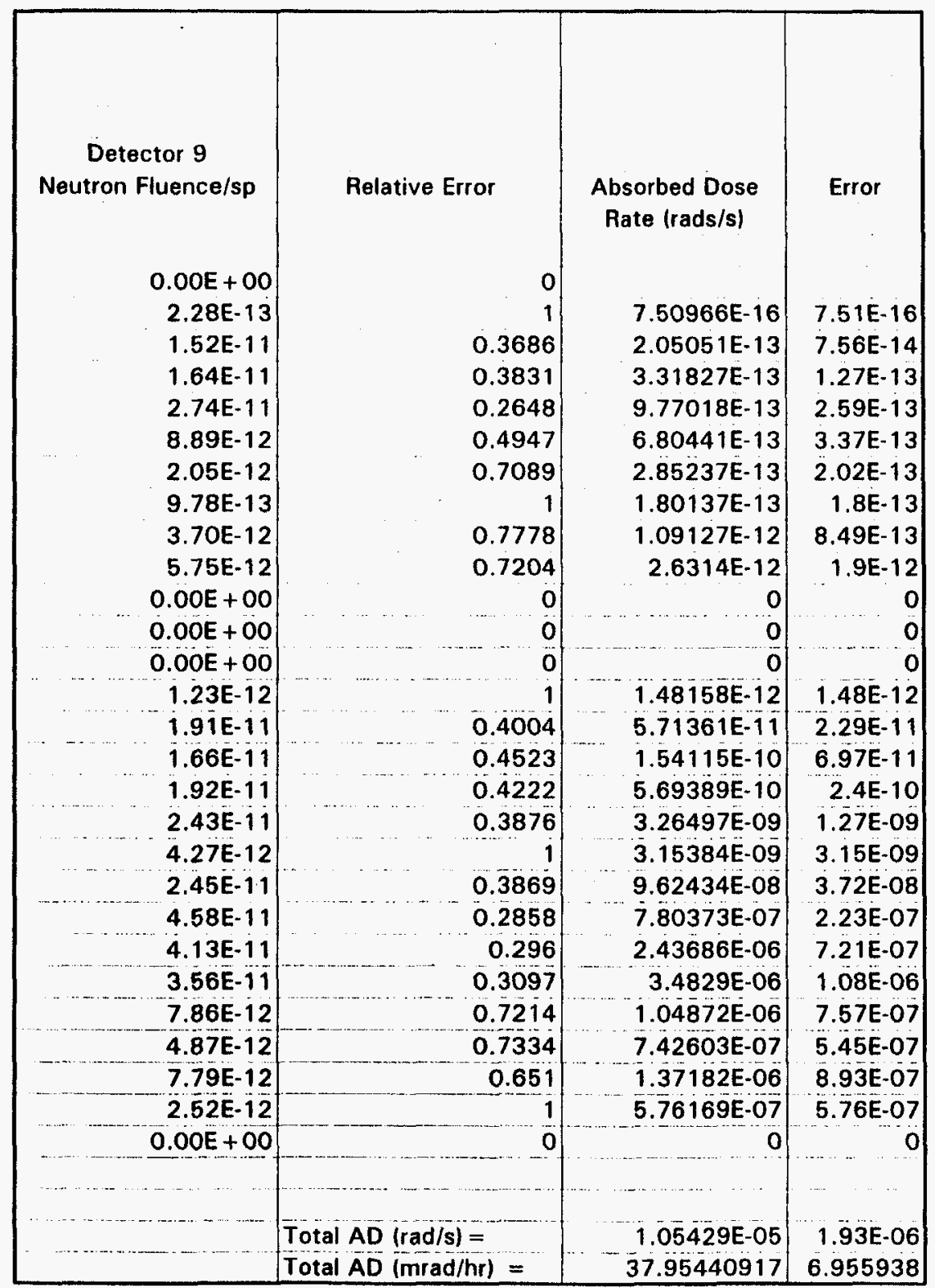




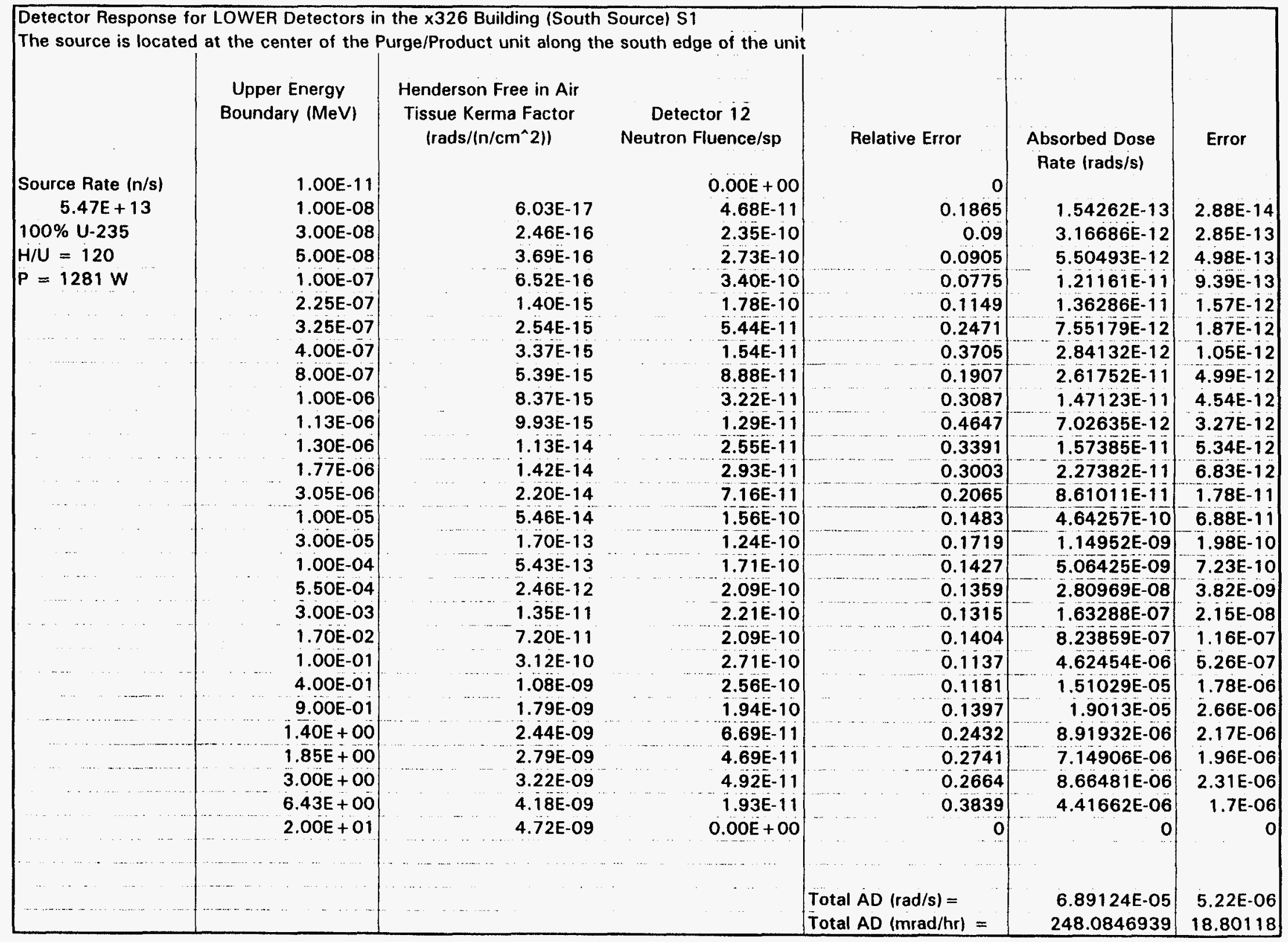




\begin{tabular}{|c|c|c|c|c|c|c|c|}
\hline $\begin{array}{c}\text { Detector } 11 \\
\text { Neutron Fluence/sp }\end{array}$ & Relative Error & $\begin{array}{l}\text { Absorbed Dose } \\
\text { Rate (rads/s) }\end{array}$ & Error & $\begin{array}{c}\text { Detector } 10 \\
\text { Neutron Fluence/sp }\end{array}$ & Relative Error & $\begin{array}{l}\text { Absorbed Dose } \\
\text { Rate (rads/s) }\end{array}$ & Error \\
\hline $0.00 E+00$ & 0 & & & $0.00 E+00$ & 0 & & \\
\hline $3.19 \mathrm{E}-11$ & 0.2369 & $1.05128 \mathrm{E}-13$ & $2.49 E-14$ & $6.22 \mathrm{E}-12$ & 0.571 & $2.0501 E-14$ & $1.17 \mathrm{E}-14$ \\
\hline $1.40 E-10$ & 0.1122 & $1.88156 \mathrm{E}-12$ & $2.11 \mathrm{E}-13$ & $1.17 \mathrm{E}-11$ & 0.4299 & $1.57778 E-13$ & $6.78 E-14$ \\
\hline $1.68 \mathrm{E}-10$ & 0.1078 & $3.38781 E-12$ & $3.65 E-13$ & $1.06 E-11$ & 0.3636 & $2.13828 E-13$ & $7.77 E-14$ \\
\hline $2.70 E-10$ & 0.0891 & $9.63815 \mathrm{E}-12$ & $8.59 \mathrm{E}-13$ & $3.08 \mathrm{E}-11$ & 0.2319 & $1.09749 \mathrm{E}-12$ & $2.55 \mathrm{E}-13$ \\
\hline $9.85 E-11$ & 0.1423 & $7.53875 \mathrm{E}-12$ & $1.07 E-12$ & $1.52 \mathrm{E}-11$ & 0.4508 & $1.16215 \mathrm{E}-12$ & $5.24 \mathrm{E}-13$ \\
\hline $3.20 E-11$ & 0.3138 & $4.43988 \mathrm{E}-12$ & $1.39 E-12$ & $1.63 \mathrm{E}-12$ & 1 & $2.25741 \mathrm{E}-13$ & $2.26 \mathrm{E}-13$ \\
\hline $1.24 \mathrm{E}-11$ & 0.4558 & $2.27924 E-12$ & $1.04 E-12$ & $2.98 \mathrm{E}-12$ & 1 & $5.49326 \mathrm{E}-13$ & $5.49 \mathrm{E}-13$ \\
\hline $5.90 \mathrm{E}-11$ & 0.2225 & $1.73804 \mathrm{E}-11$ & $3.87 \mathrm{E}-12$ & $1.36 E-12$ & $i$ & $4.01157 \mathrm{E}-13$ & $4.01 E-13$ \\
\hline $2.04 \mathrm{E}-11$ & 0.3891 & $9.31201 \mathrm{E}-12$ & $3.62 \mathrm{E}-12$ & $1.43 \mathrm{E}-12$ & 1 & $6.52205 E-13$ & $6.52 E-13$ \\
\hline $4.03 E-12$ & 0.8221 & $2.1887 \mathrm{E}-12$ & $1.8 \mathrm{E}-12$ & $0.00 E+00$ & o. & 0 & \\
\hline $4.97 \mathrm{E}-12$ & 0.5842 & $3.06835 \mathrm{E}-12$ & $1.79 E-12$ & $0.00 E+00$ & 0 & 0 & \\
\hline $2.08 \mathrm{E}-11$ & 0.3592 & $1.6183 \mathrm{E}-11$ & $5.81 \mathrm{E}-12$ & $2.55 \mathrm{E}-12$ & 1 & $1.97905 E-12$ & $1.98 \mathrm{E}-12$ \\
\hline 4.79E-11 & 0.2652 & $5.76128 \mathrm{E}-11$ & $1.53 \mathrm{E}-11$ & $9.34 \mathrm{E}-12$ & 0.5926 & $1.12321 \mathrm{E}-11$ & $6.66 \mathrm{E}-12$ \\
\hline $1.16 \mathrm{E}-10$ & 0.1651 & $3.46971 \mathrm{E}-10$ & $5.73 E-11$ & $6.90 \mathrm{E}-12$ & 0.7076 & $2.05904 E-11$ & $1.46 E-11$ \\
\hline $1.11 \mathrm{E}-10$ & 0.1732 & $1.0347 \mathrm{E}-09$ & $1.79 E-10$ & $1.70 \mathrm{E}-11$ & 0.4607 & $1.57583 \mathrm{E}-10$ & $7.26 \mathrm{E}-11$ \\
\hline $8.32 \mathrm{E}-11$ & 0.2001 & $2.47085 \mathrm{E}-09$ & $4.94 \mathrm{E}-10$ & $1.08 \mathrm{E}-11$ & 0.5044 & $3.21379 \mathrm{E}-10$ & i.62E-10 \\
\hline $1.60 \mathrm{E}-10$ & 0.1468 & $2.15209 \mathrm{E}-08$ & $3.16 \mathrm{E}-09$ & $7.07 \mathrm{E}-12$ & 0.7029 & $9.50226 \mathrm{E}-10$ & $6.68 \mathrm{E}-10$ \\
\hline $1.31 \mathrm{E}-10$ & 0.1677 & $9.66669 \mathrm{E}-08$ & $1.62 \mathrm{E}-08$ & $2.04 \mathrm{E}-11$ & 0.3849 & $1.50881 \mathrm{E}-08$ & 5.81E-09 \\
\hline $1.54 \mathrm{E}-10$ & 0.1531 & $6.07669 \mathrm{E}-07$ & $9.3 \mathrm{E}-08$ & $1.63 E-1 i$ & 0.4789 & $6.41796 \mathrm{E}-08$ & 3.07E-08 \\
\hline $1.56 \mathrm{E}-10$ & 0.155 & $2.66109 \mathrm{E}-06$ & $4.12 E-07$ & $6.01 E-12$ & 0.7154 & $1.02437 \mathrm{E}-07$ & 7.33E-08 \\
\hline $1.69 \mathrm{E}-10$ & 0.1461 & $9.95788 \mathrm{E}-06$ & $1.45 \mathrm{E}-06$ & $3.05 \mathrm{E}-11$ & 0.3463 & $1.80026 \mathrm{E}-06$ & $6.23 \mathrm{E}-07$ \\
\hline $1.23 E-10$ & 0.1651 & $1.20192 \mathrm{E}-05$ & $1.98 \mathrm{E}-06$ & 2.99E-11 & 0.3295 & 2.93077E-06 & 9.66E-07 \\
\hline $5.78 \mathrm{E}-11$ & 0.2542 & $7.71602 \mathrm{E}-06$ & $1.96 \mathrm{E}-06$ & $7.70 \mathrm{E}-12$ & 0.7146 & $1.02698 \mathrm{E}-06$ & 7.34E-07 \\
\hline $1.85 \mathrm{E}-11$ & 0.4181 & $2.81648 \mathrm{E}-06$ & $1.18 \mathrm{E}-06$ & $4.02 \mathrm{E}-12$ & 1 & $6.12504 \mathrm{E}-07$ & $6.13 \mathrm{E}-07$ \\
\hline $1.86 \mathrm{E}-11$ & 0.3783 & $3.27437 \mathrm{E}-06$ & $1.24 \mathrm{E}-06$ & 4.37E-12 & 1 & $7.69708 \mathrm{E}-07$ & 7.7E-07 \\
\hline $2.83 \mathrm{E}-12$ & 1 & $6.468 \mathrm{E}-07$ & $6.47 E-07$ & $6.88 \mathrm{E}-13$ & 1 & $1.57145 \mathrm{E}-07$ & 1.57E-07 \\
\hline $1.02 \mathrm{E}-12$ & 1 & $2.62003 E-07$ & $2.62 E-07$ & $0.00 E+00$ & o & & 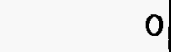 \\
\hline & $\begin{array}{l}\text { Total AD }(\mathrm{rad} / \mathrm{s})= \\
\text { Total AD }(\mathrm{mrad} / \mathrm{hr})=\end{array}$ & $\begin{array}{r}4.00837 E-05 \\
144.3011874\end{array}$ & $\begin{array}{r}3.67 E-06 \\
13.22162\end{array}$ & & $\begin{array}{l}\text { Total } A D(\mathrm{rad} / \mathrm{s})= \\
\text { Total } A D(\mathrm{mrad} / \mathrm{hr})=\end{array}$ & $\begin{array}{r}7.48054 \mathrm{E}-06 \\
26.92993657\end{array}$ & $\begin{array}{r}1.69 \mathrm{E}-06 \\
6.086508\end{array}$ \\
\hline
\end{tabular}




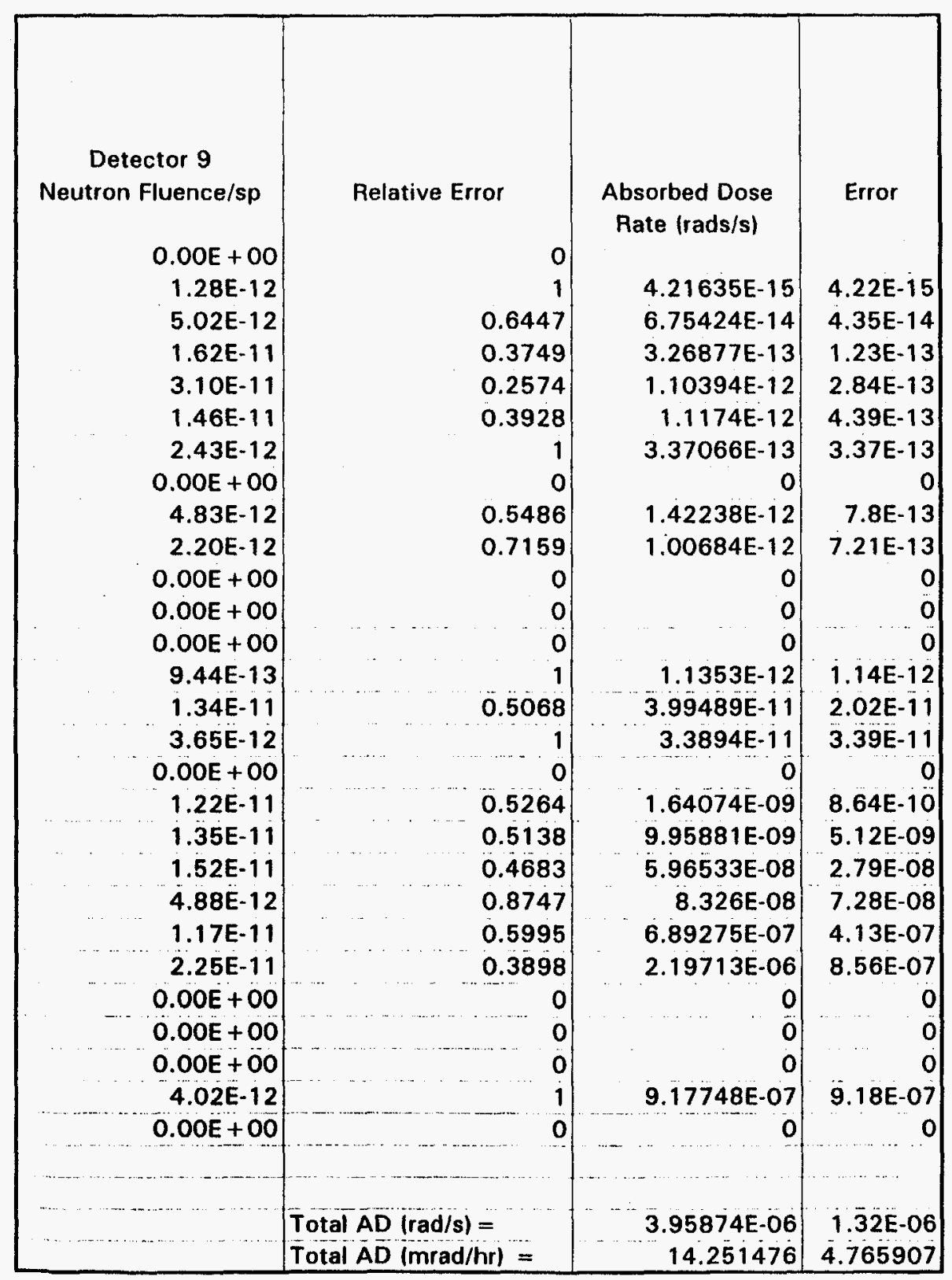




\begin{tabular}{|c|c|c|c|c|c|c|}
\hline \multicolumn{7}{|c|}{$\begin{array}{l}\text { Detector Response for UPPER Detectors in the } \times 326 \text { Building (North Source) S2 } \\
\text { The source is located at the center of the } \times 27-1 \text { unit along the north edge of the unit }\end{array}$} \\
\hline \multirow[b]{2}{*}{ Source Rate $(n / s)$} & $\begin{array}{l}\text { Upper Energy } \\
\text { Boundary (MeV) }\end{array}$ & $\begin{array}{l}\text { Henderson Free in Air } \\
\text { Tissue Kerma Factor } \\
\left.\text { (rads } /\left(\mathrm{n} / \mathrm{cm}^{\wedge} 2\right)\right)\end{array}$ & $\begin{array}{c}\text { Detector } 1 \\
\text { Neutron Fluence/sp }\end{array}$ & Relative Error & \multirow[t]{2}{*}{$\begin{array}{l}\text { Absorbed Dose } \\
\text { Rate (rads/s) }\end{array}$} & \multirow[t]{2}{*}{ Error } \\
\hline & $1.00 E-11$ & & $0.00 E+00$ & 0 & & \\
\hline $5.20 E+13$ & $1.00 \mathrm{E}-0 \mathrm{~B}$ & $6.03 E-17$ & $1.13 \mathrm{E}-11$ & 0.4892 & $3.54277 \mathrm{E}-14$ & $1.73 E-14$ \\
\hline $20 \%$ U-235 & $3.00 E-08$ & $2.46 E-16$ & 1.40E-10 & 0.1424 & $1.78905 E-12$ & $2.55 E-13$ \\
\hline$H / U=60$ & 5.00E-08 & $3.69 \mathrm{E}-16$ & $1.06 \mathrm{E}-10$ & 0.1618 & $2.04312 E-12$ & 3.31E-13 \\
\hline$P=1722 \mathrm{~W}$ & $1.00 \mathrm{E}-07$ & $6.52 \mathrm{E}-16$ & $1.87 \mathrm{E}-10$ & 0.1357 & $6.34028 \mathrm{E}-12$ & $8.6 E-13$ \\
\hline & $2.25 \mathrm{E}-07$ & $1.40 \mathrm{E}-15$ & $1.26 \mathrm{E}-10$ & 0.1811 & $9.20437 E-12$ & $1.67 E-12$ \\
\hline & $3.25 E-07$ & $2.54 E-15$ & 4.00E-11 & 0.3704 & $5.28776 E-12$ & $1.96 \mathrm{E}-12$ \\
\hline & $4.00 E-07$ & 3.37E-15 & 2.21E-11 & 0.4247 & $3.87298 E-12$ & $1.64 \mathrm{E}-12$ \\
\hline & $8.00 \mathrm{E}-07$ & $5.39 E-15$ & $4.56 E-11$ & 0.3429 & $1.27841 \mathrm{E}-11$ & 4.38E-12 \\
\hline & $1.00 \mathrm{E}-06$ & $8.37 E-15$ & 2.05E-11 & 0.4913 & $8.91928 \mathrm{E}-12$ & 4.38E-12 \\
\hline & 1.13E-06 & $9.93 E-15$ & $1.55 \mathrm{E}-11$ & 0.6223 & $8.02334 \mathrm{E}-12$ & $4.99 E-12$ \\
\hline & $1.30 \mathrm{E}-06$ & $1.13 E-14$ & $1.89 \mathrm{E}-11$ & 0.5796 & $1.11121 \mathrm{E}-11$ & $6.44 \mathrm{E}-12$ \\
\hline & $1.77 E-06$ & $1.42 E-14$ & $1.78 E-11$ & 0.5286 & $1.31183 E-11$ & $6.93 E-12$ \\
\hline & $3.05 \mathrm{E}-06$ & $2.20 E-14$ & $6.04 \mathrm{E}-11$ & 0.3053 & $6.91657 E-11$ & $2.11 \mathrm{E}-11$ \\
\hline & 1.00E-05 & $5.46 \mathrm{E}-14$ & $9.93 \mathrm{E}-11$ & 0.2356 & $2.82 E-10$ & $6.64 \mathrm{E}-11$ \\
\hline & $3.00 \mathrm{E}-05$ & $1.70 \mathrm{E}-13$ & 7.63E-11 & 0.2806 & $6.74592 \mathrm{E}-10$ & $1.89 \mathrm{E}-10$ \\
\hline & $1.00 \mathrm{E}-04$ & $5.43 E-13$ & 7.34E-11 & 0.2834 & $2.07366 \mathrm{E}-09$ & $5.88 \mathrm{E}-10$ \\
\hline & $5.50 \mathrm{E}-04$ & $2.46 \mathrm{E}-12$ & $1.11 \mathrm{E}-10$ & 0.2276 & $1.42419 \mathrm{E}-08$ & $3.24 E-09$ \\
\hline & $3.00 \mathrm{E}-03$ & $1.35 \mathrm{E}-11$ & $1.72 \mathrm{E}-10$ & 0.1983 & $1.20543 \mathrm{E}-07$ & $2.39 \mathrm{E}-08$ \\
\hline & $1.70 \mathrm{E}-02$ & $7.20 E-11$ & $8.41 E-11$ & 0.2639 & $3.1499 \mathrm{E}-07$ & 8.31E-08 \\
\hline & $1.00 \mathrm{E}-01$ & $3.12 E-10$ & $1.28 \mathrm{E}-10$ & 0.2238 & $2.07934 \mathrm{E}-06$ & $4.65 E-07$ \\
\hline & 4.00E-01 & 1.08E-09 & $2.24 \mathrm{E}-10$ & 0.1647 & $1.25597 \mathrm{E}-05$ & 2.07E-06 \\
\hline & $9.00 \mathrm{E}-01$ & $1.79 E-09$ & $1.49 \mathrm{E}-10$ & 0.2063 & $1.39146 \mathrm{E}-05$ & 2.87E-06 \\
\hline & $1.40 E+00$ & $2.44 \mathrm{E}-09$ & $5.77 \mathrm{E}-11$ & 0.306 & 7.33E-06 & 2.24E-06 \\
\hline$\ldots . .$. & $1.85 \bar{E}+00$ & 2.79E-09 & $3.94 \mathrm{E}-11$ & 0.4133 & $5.71263 E-06$ & 2.36E-06 \\
\hline & $3.00 E+00$ & $3.22 \mathrm{E}-09$ & $2.75 \mathrm{E}-11$ & 0.4717 & $4.60125 \mathrm{E}-06$ & 2.17E-06 \\
\hline & $6.43 E+00$ & 4.18E-09 & $1.42 \mathrm{E}-11$ & 0.5818 & $3.09116 \mathrm{E}-06$ & 1.8E-06 \\
\hline & $2.00 E+01$ & $4.72 \mathrm{E}-09$ & $0.00 E+00$ & & & \\
\hline$\cdots$ & $\ldots \ldots$ & & & & & \\
\hline & & & & $\begin{array}{l}\text { Total } A D(\mathrm{rad} / \mathrm{s})= \\
\text { Total } A D(\mathrm{mrad} / \mathrm{hr})\end{array}$ & $\begin{array}{r}4.97416 \mathrm{E}-05 \\
1790696789\end{array}$ & $\begin{array}{r}5.59 \mathrm{E}-06 \\
20.13869\end{array}$ \\
\hline
\end{tabular}


326NSU.XLS

\begin{tabular}{|c|c|c|c|}
\hline $\begin{array}{c}\text { Detector } 2 \\
\text { Neutron Fluence/sp }\end{array}$ & Relative Error & $\begin{array}{l}\text { Absorbed Dose } \\
\text { Pate (rads/s) }\end{array}$ & Error \\
\hline $0.00 E+00$ & 0 & & \\
\hline $2.55 \mathrm{E}-11$ & 0.3444 & $7.997 \mathrm{E}-14$ & $2.75 \mathrm{E}-14$ \\
\hline $1.09 E-10$ & 0.1837 & $1.39207 E-12$ & $2.56 E-13$ \\
\hline $1.02 E-10$ & 0.1689 & $1.9654 \mathrm{E}-12$ & $3.32 E-13$ \\
\hline $2.05 E-10$ & 0.1313 & $6.96134 E-12$ & $9.14 \mathrm{E}-13$ \\
\hline $1.10 E-10$ & 0.1903 & $8.01938 E-12$ & $1.53 E-12$ \\
\hline $1.25 E-11$ & 0.6108 & $1.64659 \mathrm{E}-12$ & $1.01 \mathrm{E}-12$ \\
\hline $2.19 \mathrm{E}-11$ & 0.5302 & $3.8369 E-12$ & $2.03 E-12$ \\
\hline $3.16 E-11$ & 0.36 & $8.84814 E-12$ & $3.19 E-12$ \\
\hline $2.29 E-11$ & 0.4943 & $9.95781 \mathrm{E}-12$ & $4.92 \mathrm{E}-12$ \\
\hline $1.10 E-11$ & 0.7147 & $5.69547 \mathrm{E}-12$ & $4.07 E \cdot 12$ \\
\hline $8.75 E-12$ & 0.8002 & $5.14406 E-12$ & $4.12 \mathrm{E}-12$ \\
\hline $2.10 \mathrm{E}-11$ & 0.5045 & $1.54917 \mathrm{E}-11$ & $7.82 E-12$ \\
\hline $3.66 \mathrm{E}-11$ & 0.3745 & $4.19401 \mathrm{E}-11$ & $1.57 \mathrm{E}-11$ \\
\hline $9.95 \mathrm{E}-11$ & 0.2343 & $2.82516 \mathrm{E}-10$ & $6.62 E-11$ \\
\hline $7.61 E-11$ & 0.2761 & $6.7264 \mathrm{E}-10$ & $1.86 \mathrm{E}-10$ \\
\hline $1.06 E-10$ & 0.2292 & $3.00671 \mathrm{E}-09$ & $6.89 E-10$ \\
\hline $1.85 \mathrm{E}-10$ & 0.1841 & $2.36895 \mathrm{E}-08$ & $4.36 \mathrm{E}-09$ \\
\hline $1.48 \mathrm{E}-10$ & 0.2093 & 1. $03613 E-07$ & $2.17 \mathrm{E}-08$ \\
\hline $1.34 \mathrm{E}-10$ & 0.2188 & $5.03069 \mathrm{E}-07$ & 1.1E-07 \\
\hline $1.73 \mathrm{E}-10$ & 0.1925 & $2.81512 E-06$ & $5.42 \mathrm{E}-07$ \\
\hline $1.88 \mathrm{E}-10$ & 0.1865 & $1.05474 \mathrm{E}-05$ & 1.97E-06 \\
\hline $6.39 E-11$ & 0.2879 & $5.95104 \mathrm{E}-06$ & $1.71 \mathrm{E}-06$ \\
\hline $6.62 E-11$ & 0.3031 & $8.40831 E-06$ & $2.55 \mathrm{E}-06$ \\
\hline $2.91 E-11$ & 0.4129 & $4.23019 E-06$ & $1.75 \mathrm{E}-06$ \\
\hline $2.81 E-11$ & 0.4704 & $4.70418 \mathrm{E}-06$ & $2.21 \mathrm{E}-06$ \\
\hline $2.83 \mathrm{E}-11$ & 0.4312 & $6.15565 \mathrm{E}-06$ & 2.65E-06 \\
\hline $0.00 E+00$ & 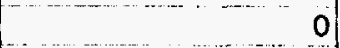 & & \\
\hline$-\ldots \ldots \ldots \ldots$ & \begin{tabular}{|lllll} 
& $\ldots$ & $\ldots$ & & \\
\end{tabular} & $\ldots .$. & \\
\hline & Total AD $(\mathrm{rad} / \mathrm{s})=$ & $4.34463 E-05$ & 5.35E-06 \\
\hline & Total $A \bar{D}(\mathrm{mrad} / \mathrm{hr})=$ & 156.4066615 & 19.25213 \\
\hline
\end{tabular}




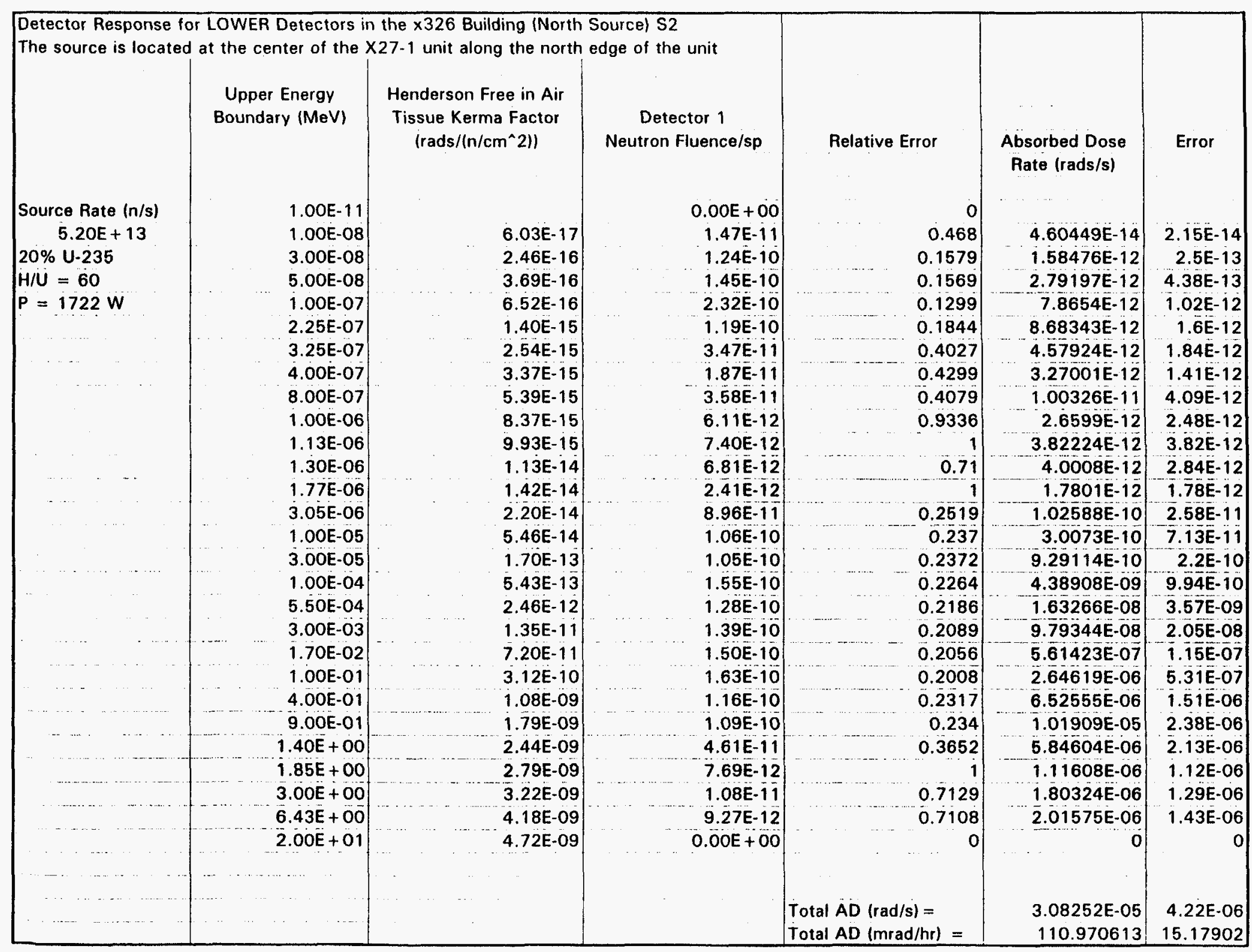




\begin{tabular}{|c|c|c|c|}
\hline $\begin{array}{c}\text { Detector } 2 \\
\text { Neutron Fluence/sp }\end{array}$ & Relative Error & $\begin{array}{l}\text { Absorbed Dose } \\
\text { Rate (rads/s) }\end{array}$ & Error \\
\hline $0.00 E+00$ & o & & \\
\hline $2.41 \mathrm{E}-11$ & 0.329 & $7.5672 \mathrm{E}-14$ & $2.49 E-14$ \\
\hline $1.34 \mathrm{E}-10$ & 0.1655 & $1.71782 \mathrm{E}-12$ & $2.84 E-13$ \\
\hline $1.19 E-10$ & 0.1594 & $2.27795 \mathrm{E}-12$ & $3.63 E-13$ \\
\hline $2.19 E-10$ & 0.1242 & $7.41691 E-12$ & $9.21 E-13$ \\
\hline $7.13 E-11$ & 0.2411 & $5.19336 \mathrm{E}-12$ & $1.25 \mathrm{E}-12$ \\
\hline $7.86 E-12$ & 0.828 & $1.0386 \mathrm{E}-12$ & 8.6E-13 \\
\hline $1.20 E-11$ & 0.703 & $2.09655 \mathrm{E}-12$ & $1.47 E-12$ \\
\hline $2.22 E-11$ & 0.5343 & $6.21482 E-12$ & $3.32 \mathrm{E}-12$ \\
\hline $1.52 E-11$ & 0.546 & $6.6053 E-12$ & $3.61 \mathrm{E}-12$ \\
\hline $1.02 E-11$ & 0.5671 & $5.25066 \mathrm{E}-12$ & $2.98 \mathrm{E}-12$ \\
\hline 7.9OE-12 & 0.8163 & $4.64256 \mathrm{E}-12$ & $3.79 E-12$ \\
\hline 4.86E-11 & 0.3436 & $3.58981 \mathrm{E}-11$ & $1.23 E-11$ \\
\hline 3.1OE-11 & 0.4032 & 3.54854E-11 & $1.43 \mathrm{E}-11$ \\
\hline $1.02 E-10$ & 0.2282 & $2.91039 E-10$ & $6.64 \mathrm{E}-11$ \\
\hline $8.00 E-11$ & 0.2779 & $7.0746 \mathrm{E}-10$ & $1.97 \mathrm{E}-10$ \\
\hline $1.29 \mathrm{E}-10$ & 0.2189 & $3.64955 \mathrm{E}-09$ & $7.99 \mathrm{E}-10$ \\
\hline 1.09E-10 & 0.2482 & $1.39471 \mathrm{E}-08$ & $3.46 \mathrm{E}-09$ \\
\hline $9.15 E-11$ & 0.2589 & $6.42703 E-08$ & $1.66 \mathrm{E}-08$ \\
\hline $1.62 \mathrm{E}-10$ & 0.1977 & $6.08222 \mathrm{E}-07$ & $1.2 E-07$ \\
\hline $1.80 \mathrm{E}-10$ & 0.1878 & 2.91542E-06 & 5.48E-07 \\
\hline 1.34E-10 & 0.2127 & $7.5489 \mathrm{E}-06$ & 1.61E-06 \\
\hline $1.19 \mathrm{E}-10$ & 0.2291 & $1.10852 \mathrm{E}-05$ & 2.54E-06 \\
\hline $4.85 E-11$ & 0.3581 & 6.16195E-06 & 2.21E-06 \\
\hline $2.20 \mathrm{E}-11$ & 0.5147 & $3.19204 \mathrm{E}-06$ & $1.64 \mathrm{E}-06$ \\
\hline $4.13 \mathrm{E}-11$ & 0.3734 & $6.91364 E-06$ & 2.58E-06 \\
\hline $1.17 \mathrm{E}-11$ & 0.7466 & $2.54881 E-06$ & 1.9E-06 \\
\hline $5.88 E-12$ & 1 & $1.4438 \mathrm{E}-06$ & $1.44 E-06$ \\
\hline & $\begin{array}{l}\text { Total AD }(\mathrm{rad} / \mathrm{s})= \\
\text { Total } A D(\mathrm{mrad} / \mathrm{hr})=\end{array}$ & $\begin{array}{r}4.2501 \mathrm{E}-05 \\
153.0036502 \\
\end{array}$ & $\begin{array}{r}5.41 \mathrm{E}-06 \\
19.48024 \\
\end{array}$ \\
\hline
\end{tabular}




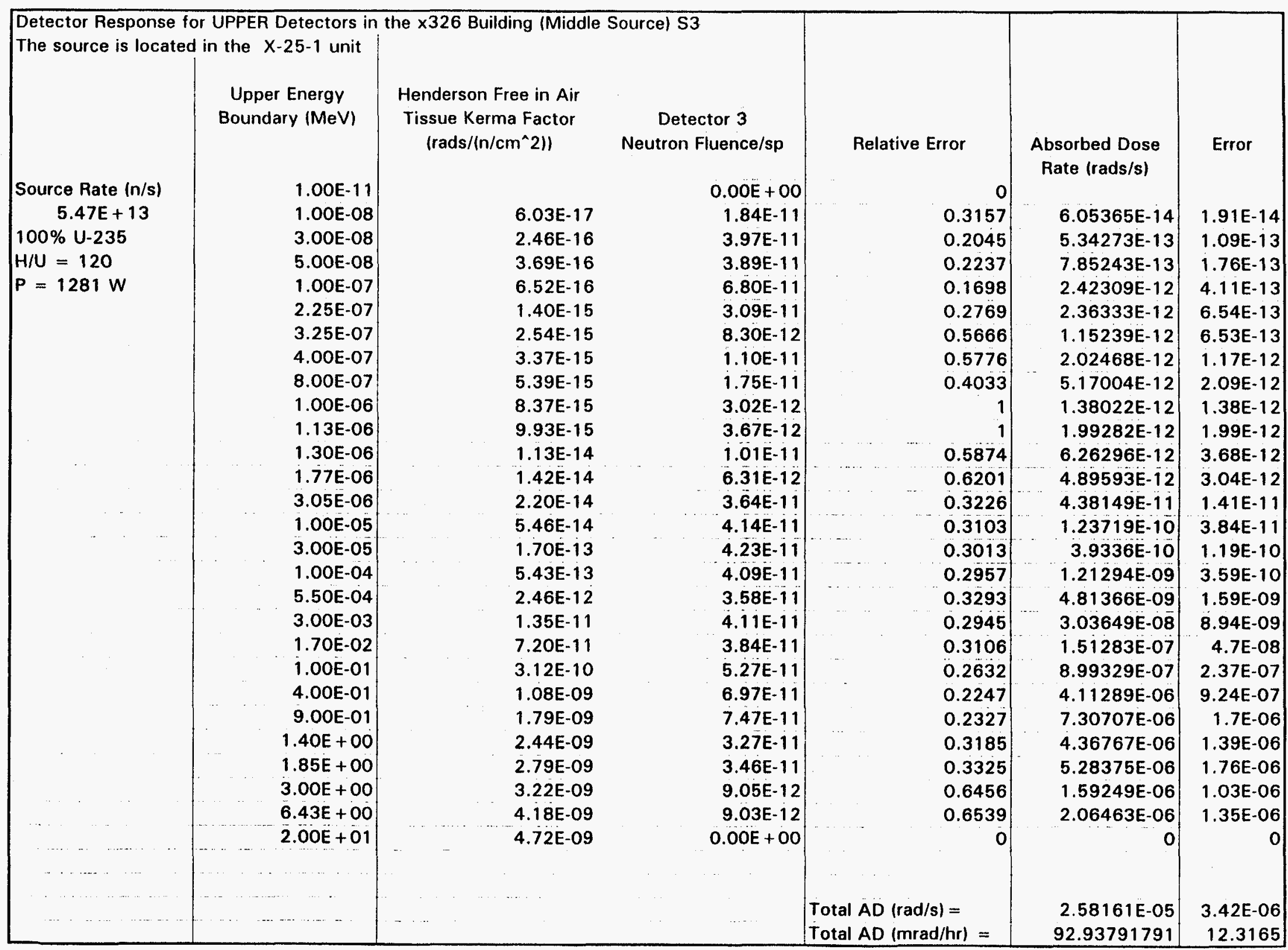




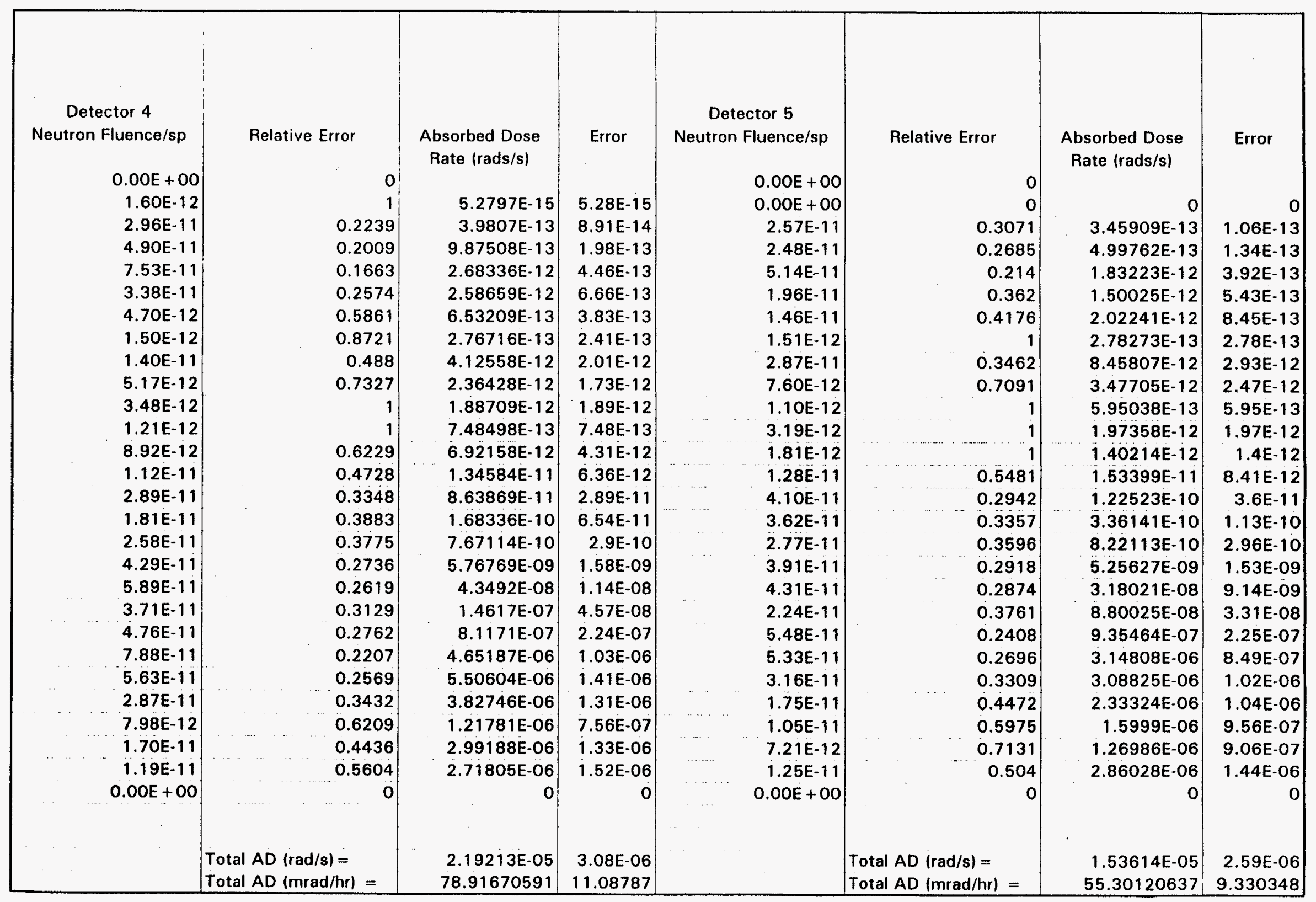


326MSU.XLS

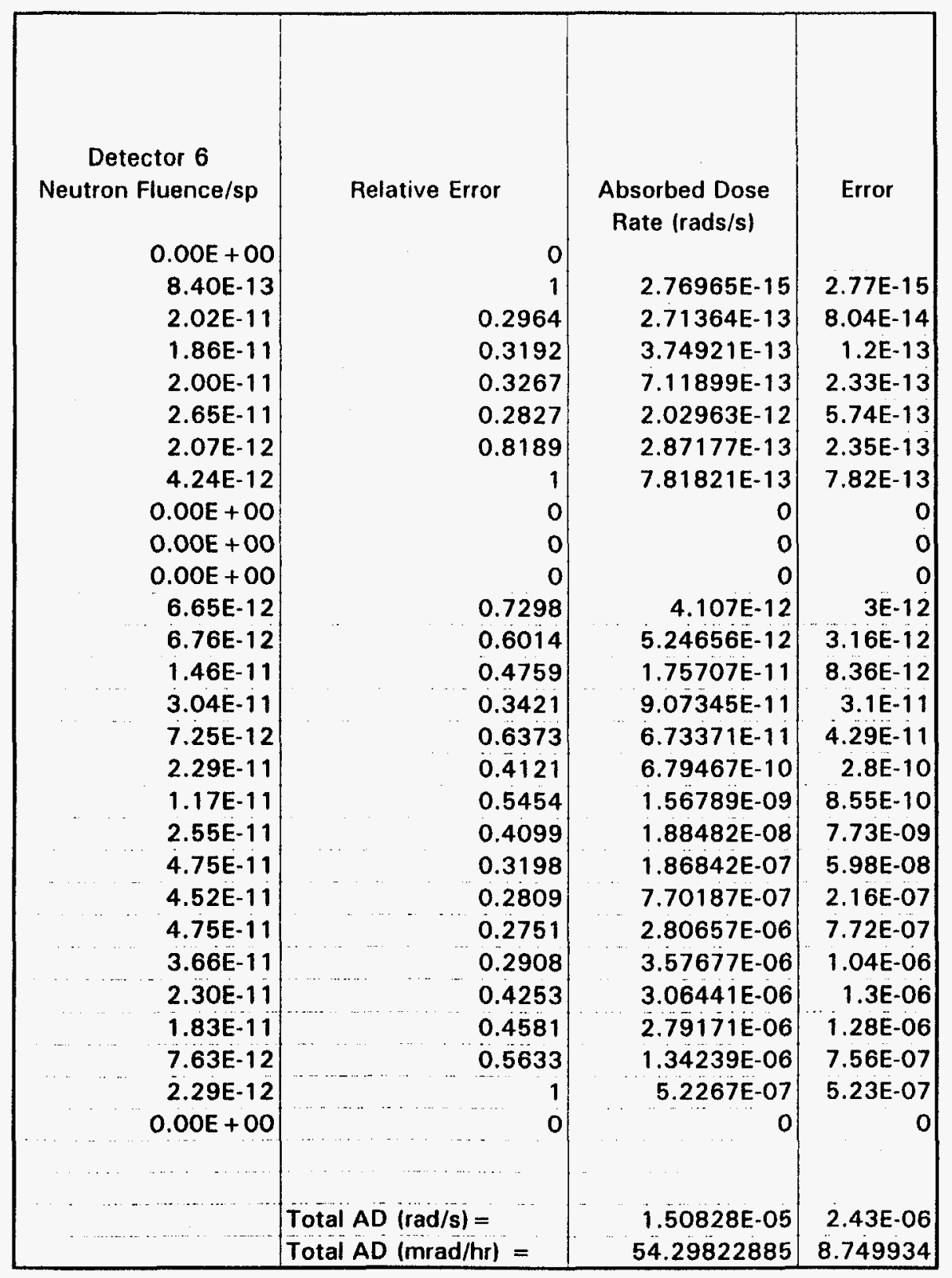


326MSL.XLS

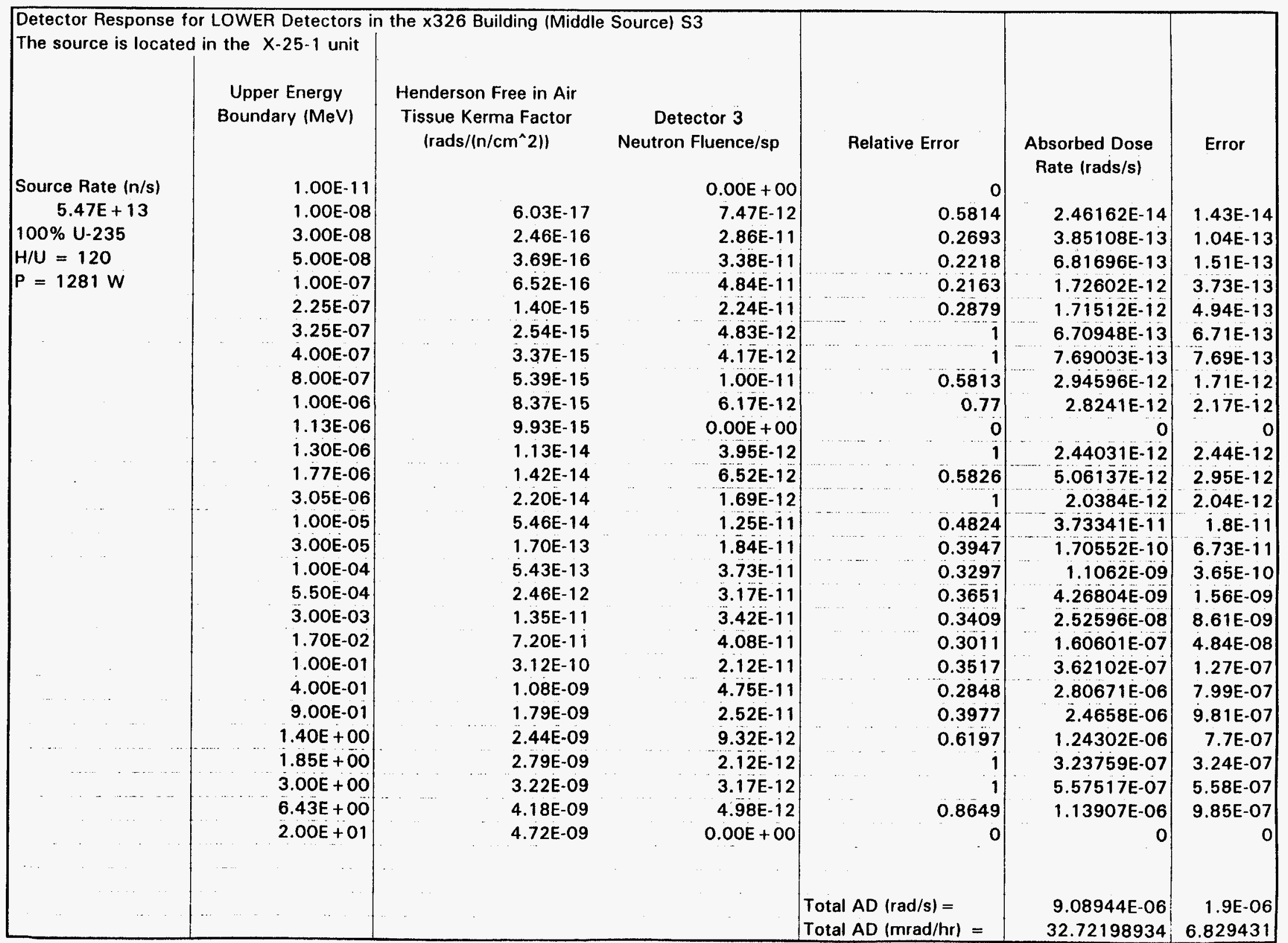




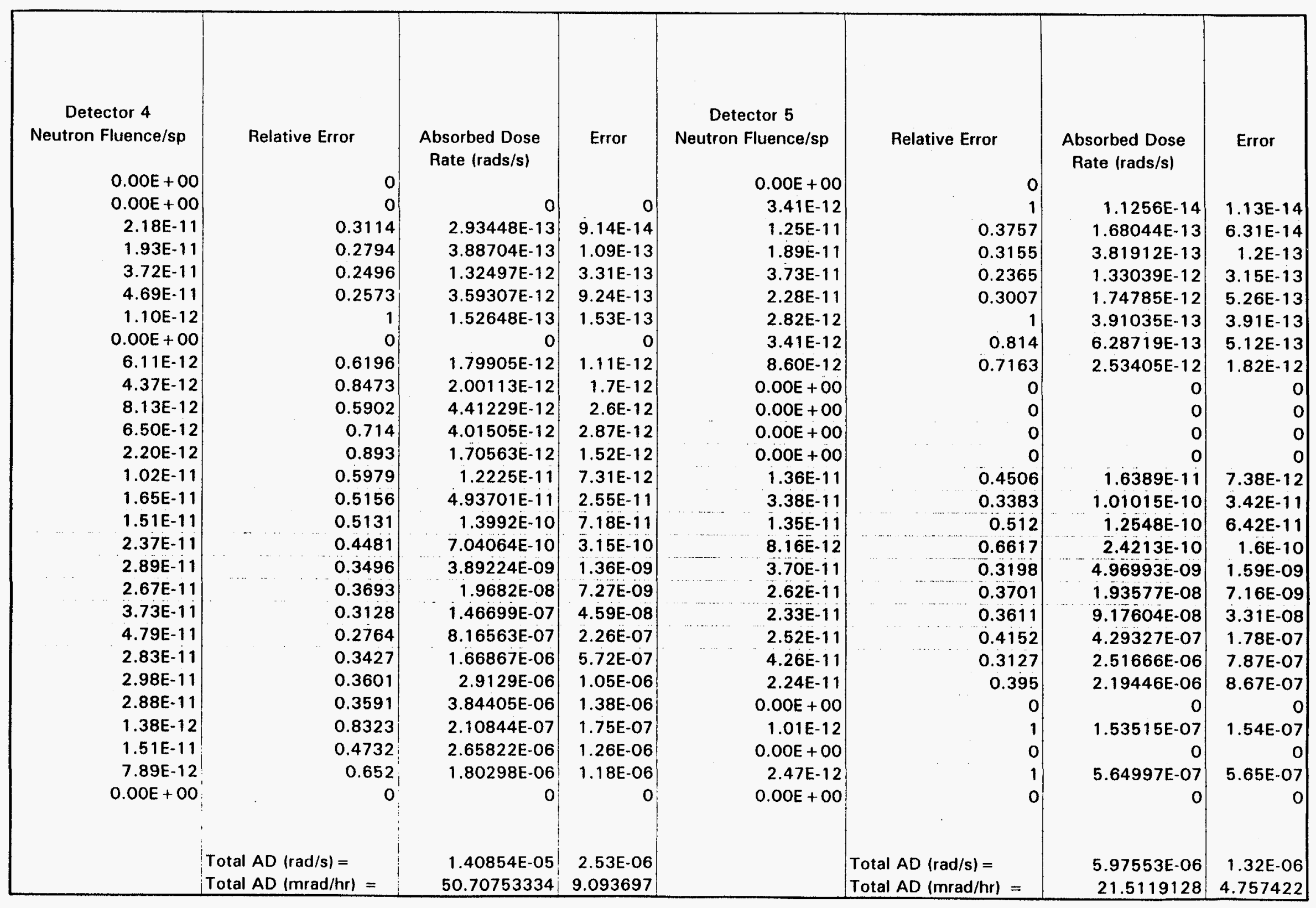




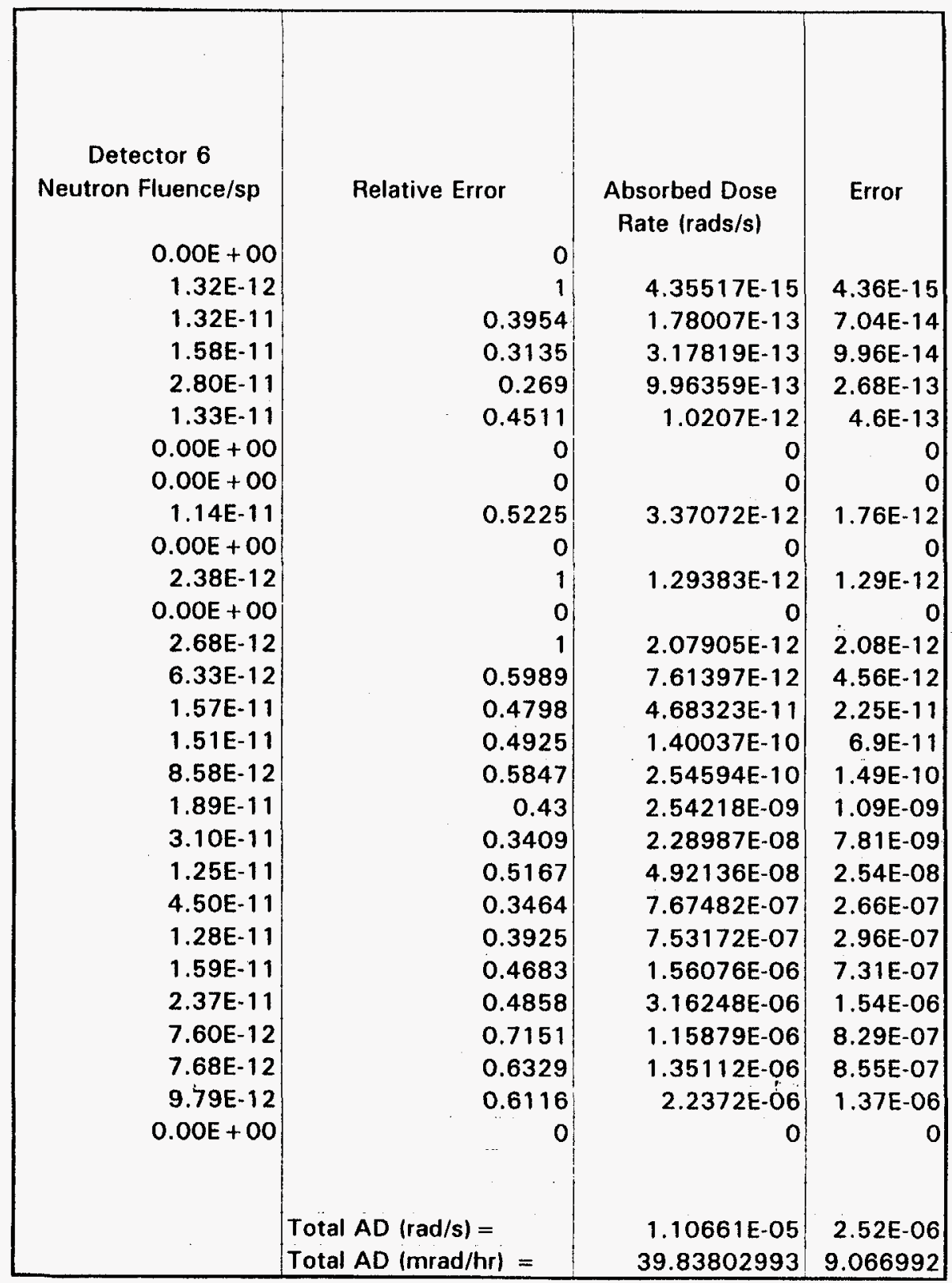

